\title{
On İkinci Sınıf Öğrencilerinin Yükseköğretim Programı Seçimlerini Etkileyen Faktörler ve Öğretmenlik Programlarını Tercih Etme Durumları ${ }^{1}$
}

DOI: $10.26466 /$ opus.567578

\section{Hasan Güner Berkant* - Sevim Bahadır**}

* Doç. Dr., Kahramanmaraş Sütçü İmam Üniversitesi Eğitim Fakültesi, Kahramanmaraş/Türkiye E-Posta: hgberkant@gmail.com

ORCID: 0000-0003-0725-6036

** Çukurova Elektrik Anadolu Lisesi, Onikişubat/Kahramanmaraş/ Türkiye E-Posta: sevimbaha@hotmail.com

ORCID: $\quad$ 0000-0002-3242-7397

\section{Öz}

Bu çalışmanın genel amacı on ikinci sınıf öğrencilerinin, yükseköğretim programı seçimlerini etkileyen faktörleri ve öğretmenlik programların tercih etme durumların belirlemektir. Araştırmanın örneklemini Kahramanmaraş ili merkez ilçelerindeki devlet okullarının on ikinci sınıfında öğrenim gören 100 öğrenci oluşturmaktadır. Araştırmada nitel araştırma yöntemlerinden görüşme yöntemi kullanılmıştır. Görüşmeler yoluyla elde edilen verilerin çözümlenmesi için içerik analizi yöntemi kullanılmıştır. Verilerin analizi sonucunda ulaşılan bulgulara göre; araştırmaya katılan on ikinci sınıf öğrencilerinin çoğunun kişisel özelliklerinin, ilgi ve yeteneklerinin yükseköğretim programı seçimlerinde etkili olabileceği sonucuna ulaşılmıştır. Ayrıca yükseköğretim programlarının mezunlarına sağlayabileceği iş imkân ve maddi kazancın, üniversitelerin yurt dışı eğitim, burs, yurt gibi olanaklarının, yükseköğretim programlarının toplum üzerindeki imajı ve saygınlığının, yükseköğretim programının ve bağh olduğu üniversitenin akademik kadrosunun öğrencilerin yükseköğretim programı seçiminde etkili olabileceği yönünde bulgulara ulaşılmıştır. Ancak öğrencilerin çŏ̆unun yükseköğretim programı seçimlerinde aile ve arkadaşlarının etkili olmadığı sonucuna varılmıştır. Öğrencilerden çoğunun öğretmenlik mesleğini hem zor hem de çok fazla emek isteyen bir meslek olarak görmesi ve ayn konuyu tekrar anlatmayı zor bulmaları gibi çeşitli nedenlere bağlı olarak, seçimlerinde öğretmenlik programlarına yer vermeyecekleri yönünde bulgulara ulaşılmıştır.

Anahtar Kelimeler: Yükseköğretim programı, Öğretmen yetiştirme programları, Program tercihi, Lise öğrencileri.

\footnotetext{
${ }^{1}$ Bu çalışma, Sevim Bahadır'ın Kahramanmaraş Sütçü Imam Üniversitesi Sosyal Bilimler Enstitütüsü’nde tamamladığı (2019) yüksek lisans tezinden üretilmiş olup, ICES_UEBK 2019'da sözlü bildiri olarak sunulmuştur.
} 


\title{
Factors Affecting Twelfth Grade Students' Higher Education Choices and Their Preferences for Teacher Education Programs
}

\begin{abstract}
The main objective of this study is to determine the factors that affect the students' choice of higher education program and their situations of preferring teacher education programs. The sample of the study consisted of 100 students studying in the twelfth grade of the public schools in the central districts of Kahramanmarass. In the research, interview method, that is one of the qualitative research methods, was used. Content analysis method was utilized to analyze the data obtained through interviews. According to the findings of the data analysis it was concluded that the most of the high school students' personal characteristics, interests and abilities could be effective in their selection of higher education program. In addition, it was found that the opportunities of employment and financial gain that the university provides for its students, universities' opportunities of scholarship, dormitory and overseas education, the image and reputation of higher education programs on the society and the academic staff of the university could be effective on the choice of higher education program. However, it was concluded that most students' families and friends wouldn't be effective in their choice of higher education program. It was found that most of the students would not include teacher education programs in their choices due to various reasons such as seeing the teaching profession as a difficult and very demanding profession and finding it difficult to teach the same subject again.
\end{abstract}

Keywords: Higher education program, Teacher education programs, Program choise, High school students 


\section{Giriş}

Ortaöğretim dönemi bireylerin 15-18 yaş aralığını kapsayan, onlara bir meslek edindirebilmek için bir üst öğrenim kurumu olan yükseköğretime hazırlamayı hedefleyen eğitim dönemidir (Çurğatay, 2010). Türkiye'de ortaöğretim düzeyinde öğrenciler, milli eğitimin genel hedefleri ve temel ilkelerine uygun bir şekilde, ortak bir genel kültürle beraber, ilgi alanları ve kabiliyetleri doğrultusunda yükseköğretim kurumlarına hazırlanmakta olup, bu sayede hem mesleki hem de yaşamsal becerileri kazanmaya hazır hale getirilmeye çalışılmaktadır (Özgüven, 2001). Bu bağlamda, ortaöğretimin işlevlerinden biri öğrencileri yükseköğretime hazırlamaktır (Yeşilyaprak, 2000). Yükseköğretime geçişte öğrencilerin, ortaöğretimde kazandırılması amaçlanan temel bilgi ve zihinsel becerileri ne derece kazanmış oldukları, öğrencilerin öğrenme güçlerini ne derece geliştirdikleri ölçüt olarak kullanılmaktadır (Özgüven, 2001). Ancak günümüzde bireylerin meslek seçimlerinin ilgi, yetenek ve becerilerine göre olmaktan ziyade çoğunlukla yükseköğretime giriş sınavlarından aldıkları puana göre gerçekleştiği görülmektedir. Bu nedenle öğrenciler hem kişisel istekleri hem de ebeveynlerinin kendilerinden beklentileri konusunda çatışmaya düşebilmektedirler. Yine de öğrencilerin bir konuda en iyisini ortaya koyabileceklerini düşündükleri etkinliklere ve bireysel olarak kendilerini en üst düzeyde doyuma götürebileceğine inandıkları alanlara ve mesleklere doğru bir yönelim göstermeleri beklenmektedir (Şirin, Öztürk, Bezci, Çakar ve Çoban, 2004).

İnsanların belli bir yaş aralığından sonraki yaşamlarında onların başarılı olmalarını ve mutlu bir birey olarak gelişmelerini, böylelikle kendilerini gerçekleştirmelerini etkileyecek en önemli olaylardan biri meslek seçimidir (Kepçeoğlu, 1996). Meslek, bireyin kişisel bütünlüğünün en temel kaynağı olup, bireyin etrafından saygı görmesine, başka insanlarla ilişkiler oluşturabilmesine, sosyal yaşamda kendisine bir yer elde etmesine ve işe yarama duygusunu yaşayabilmesine imkân veren bir duygudur. Mesleki etkinliklerle birlikte bireyler potansiyellerini kullanarak bazı ürünler ortaya koyarlar (Kuzgun, 2009). Bu ürünlerin kaliteli olmasında meslek seçimi önemli bir aşama olup, bu seçimlerinin sağlıklı olmasında mesleki rehberlik çalışmaları önemli bir yer tutmaktadır. 
Mesleki rehberlik, Rehberlik Hizmetleri Yönetmeliği'nde (MEB, 2018) şöyle tanımlanmaktadır: "Kişinin öncelikle kendisini ve meslek dallarmı tanıması; yetenekleri, ilgileri, bireysel ihtiyaçlar, değerler sistemi ve kişisel nitelikleri doğrultusunda bir mesleği seçmeye yönelmesi; o mesleğe hazırlanması, mesleğe başlaması ve sürdürmesi, yaşam boyu öğrenme ekseninde kendini geliştirmesi için bireye ve ailesine sunulan hizmetlerdir." Ergenlik dönemindeki bir bireyin, toplumsal açıdan sorumluluklarını öğrenebilmesi ve davranışlarıyla ilgili olarak rehberlik edecek değerleri kazanması konularına yönelik yardıma ihtiyacı bulunmaktadır (Yavuzer, 2001). Ortaöğretim kurumlarında mesleki rehberlik çalışmaları ilköğretimdeki rehberlik çalışmalarından daha farklıdır. Gencin, ergenlik dönemini kapsadığı varsayılan 15-18 yaşları ortaöğretim dönemine denk düşmektedir. Dolayısıyla genç, hem içinde bulunduğu gelişim özelliklerinin getirdiği farklılaşmalarla baş edecek, hem geleceğini şekillendirecek olan meslek seçimi için doğru bir karar vermeye çalışacak, hem de geleceğini etkileyecek olan üniversite sınavına hazırlanacaktır. Ortaöğretim kurumlarının tüm bu durumları dikkate alması ve ihtiyaçların karşılanması için öğrencilerin gelişim özelliklerini de dikkate alarak mesleki rehberlik çalışmalarını gerçekleştirmesi gerekmektedir (Coşkun, 2006). Bununla birlikte, lisede eğitim-öğretim sürecini tamamladıktan sonra iş hayatına başlama konumunda olan bireylerin ilgilerine ve becerilerine uygun olan çalışma alanlarına yönlendirilmesi ve yerleştirilmesi işlemlerinde de profesyonel bir yardıma ihtiyaçları bulunmaktadır (Yüksel ve Şahin, 2008).

Kişinin meslek seçiminde bulunmak üzere odaklandığı her gelişim döneminde birbirinden farklı kararlar vermesinde çeşitli faktörler önemli rol oynamaktadır. Bu faktörlerden bazıları; cinsiyet özellikleri ve fiziksel özellikler, bireyin kendi istekleri ve hayalleri, mesleğin toplum içindeki yeri, mesleğin kazanç miktarı ve o mesleğe toplumun göstermiş olduğu talep, öğrencilerin akademik başarısı, öğretmenlerin düşünceleri, ailelerin çocuklarından beklentileri ve kendileriyle ilgili fikirleri, öğrencilerin çalışma alışkanlıkları ve okul başarı durumu, benlik kavramı, ilgi alanları, özel yetenekleri ve zeka düzeyi, arkadaşların etkileri ve fikirleri, ailelerin sosyo-ekonomik durumu, ülkenin ekonomik tablosu, teknoloji alanında yaşanan gelişmeler, meslek alanlarıyla ilgili bilgi seviyesi ve mesleki olgunluk düzeyi şeklinde sıralanabilir (Deniz, 2001). Bireylerin bir meslek 
edinebilmesi için gerekli ön koşullardan biri olan yükseköğretim programı seçim aşamasında etkili olan faktörler araştırmalara konu olmaya devam etmektedir. Paa ve McWhirter'in (2000) lise öğrencilerinin mevcut kariyer beklentileri üzerinde algılanan etkileri konulu çalışmalarında, ergenlerin kariyer beklentilerinin kişisel, geçmiş ve çevresel faktörlerden etkilendiği sonucuna varılmıştır. Gushue, Clarke, Pantzer ve Scanlan (2006), daha yüksek düzeydeki kariyer karar verme öz-yeterliğinin hem daha farklılaşmış bir mesleki kimlikle, hem de kariyer edinme yükümlülükleriyle daha fazla meşgul olmakla ilişkili olduğunu ortaya koymuşlardır. Borchert (2002) tarafından lise öğrencilerinin kariyer seçimini etkileyen faktörler üzerine bir araştırmada, kariyer planlaması verimli bir şekilde yapıldığında öğrencilerin rastlantısal bir durumdan ziyade bilinçli yapılmış bir kariyer planını takip edebildikleri vurgulanmıştır. Kılınç (2007) üniversite seçiminde öğrenci yönelimlerini etkileyen faktörleri incelediği çalışmasında, öğrencilerin öğrenim gördükleri bölümü meslek sahibi olmak için seçenlerin oranının \%61,9, yetenek ve ilgi alanlarına uygun olduğu için seçenlerin oranının \%51,6, puanı tuttuğu için seçenlerin oranının $\% 40,5$, iş bulma olanağından dolayı seçenlerin oranının $\% 34,2$, bölümün güncelliği nedeniyle seçenlerin oranının $\% 28,6$, toplumda saygın bir yeri olduğu için seçenlerin oranının \%22,2 ve ekonomik kazancının iyi olacağını düşündüğü için seçenlerin oranının \%21,1 olduğu sonucuna ulaşmıştır. Vurucu (2010), meslek lisesi öğrencilerinin meslek seçimi yeterliliği ve meslek seçimini etkileyen faktörleri araştırdığ 1 çalışmasında, meslek seçiminde ailelerin sosyo-ekonomik durumlarının etkili olduğunu kabul eden öğrencilerin \%41, ailelerin beklentisi ve öğrencilere yönelik düşüncelerin etkili olduğunu kabul eden öğrencilerin \%59, meslek seçiminde arkadaşların ve çevrenin etkili olduğunu kabul eden öğrencilerin ise \%47 oranında olduğu sonucuna ulaşmıştır. Çiftçi, Bülbül, Bayar-Muluk, Çamur-Duyan ve Yılmaz (2011) çalışmalarında kendi isteği ile tercih yapan öğrencilerin oranının \%70,32 olduğunu belirlemişlerdir. Korkut Owen, Kepir, Özdemir, Ulaş ve Yılmaz (2012) tarafından yapılan araştırmada, üniversite bölümü seçmenin ilk dört nedeninin "alana duyulan ilgi, alınan puanın bu bölüme yetmesi, alanın kişilik özelliklerine uygunluğu ve iş bulma olanağının yüksekliği" olduğu bulgularına ulaşılmıştır. 
Nagel (1999) tarafından kaleme alınan ve eski bir Çin kitabı olan Tao Te Ching'in seksen bir bölümden oluşan "Öğrenimin Taosu” adlı eserde öğretmenlerle ilgili şu ifadeler dikkate değerdir: "Bilge öğretmenler, yoğun çalışmalarını devam ettirebilmek amacıyla kendilerine karşı güven hissedilmesini beklerler. Onlara itibar veya servet verilmesini beklemezler. Onlar içten gelen motivasyonun en iyi örnekleridirler. Çünkü, bir şey yapılması gerektiği zaman, o şey özel bir ödül olmadan yapılır. Öğretmek, çok iyi öğretmenler için zihinlerinde kendiliğinden oluşan bir hediyedir. İyi bir gün demek, öğrenmenin meydana gelmesi demektir; iyi öğretmenler ertesi günü heyecan içinde beklerler ve ortaya koyulan gayretin yapılan çalışmaya değer olduğunu hissederler." Bu ifadeden de anlaşılabileceği üzere, öğretmenlik mesleği bir alanda uzmanlığı yani profesyonelliği gerekli kılmanın ötesinde, bu mesleği icra edecek olan kişilerin duyguları ve düşünceleri ile de yakından ilişkilidir (Özbek, Kahyaoğlu ve Özgen, 2007). Öğretmenlik mesleğinin gerektirdiği becerilere sahip olan öğretmenlerin yetiştirilmesi gayreti, belirli özelliklere sahip insan yetiştirme sisteminin ana belirleyicisi konumundadır (Azar, 2011). Günümüz toplumunda öğretmenlik mesleği, toplumsal saygınlığı görece düşük olan meslek alanları arasında bulunmakla beraber, insanların çoğu tarafından basit ve hemen herkesin yapabileceği bir iş olarak nitelendirilmeye başlandığından dolayı, "hiçbir şey olamazsan öğretmen ol" sözü toplum tarafından yaygın olarak kullanılır hale gelmiştir (Özsoy, Özsoy, Özkara ve Memiş, 2010). Öğrencilerin devamlı bir istek içerisinde bulunmalarından dolayı öğretmenlik yapabilecek niteliklere sahip adayları bulmak da zorlaşmaktadır (Eraslan, 2004). Öğretmenlik mesleğinin tercih edilme durumlarıla ilgili araştırmalar incelendiğinde; Demir ve Arı (2013) tarafından yapılan çalışmada öğretmenler için en rahatsız edici sorunların başında "gelirin düşük olması", "toplumdaki saygınlığın düşmesi" ile "sık değişen programlar ve mevzuatlar" olduğu sonucu ortaya çıkmıştır. Yılmaz ve Doğan (2015) tarafından yapılan çalışmada, ilköğretim matematik öğretmenliği adaylarının matematik öğretmenliğini seçmelerinde etkili olan en önemli faktörün "kişiliğe uygun olması", en az etkili olan faktörün ise "geleneksel öğretmenlerin yerini alma isteği" olduğu bulgularına ulaşılmıştır. Özbek (2007) 
araştırmasında öğretmenlik mesleğini tercihte ekonomik ve sosyal faktörlere kıyasla kişisel tercih ile ilgili faktörlerin daha etkili olduğu sonucuna ulaşmıştır.

Yukarıdaki araştırmalardan farklı olarak bu çalışmada, lise son sınıf öğrencilerinin yükseköğretim programı seçimini etkileyen faktörler ve öğretmenlik programlarını tercih etme durumları bir arada ele alınmaktadır. Öğrencilerin yükseköğretim programı seçimlerinde hem öğretmenlik programlarını hem de diğer programları belirlerken kişisel yetenek ve ilgileri başta olmak üzere kendileri için önemli gördükleri ölçütleri belirlemelerinin, Türkiye'de yükseköğretimin kalitesinin artmasına ve doğru tercihlerin başarılı meslek elemanlarına dönüşmesine katkı sağlayacağ düşünülmektedir. Bu bağlamda çalışmanın problem cümlesi "On ikinci sınıf öğrencilerinin yükseköğretim programı seçimlerini etkileyen faktörler ve öğretmenlik programlarını tercih etme durumları nelerdir?" şeklinde belirlenmiştir.

\section{Araştırmanın Amacı}

Araştırmanın genel amacı, on ikinci sınıf öğrencilerinin yükseköğretim programı seçimlerini etkileyen faktörlerin ve öğretmenlik programlarını tercih etme durumlarının incelenmesidir. Bu genel amaç doğrultusunda aşağıda belirtilen sorulara yanıt aranmıştır:

On ikinci sinıf öğrencilerinin;

1. Kişisel özelliklerinin, yetenek ve ilgi alanlarının yükseköğretim programı seçimlerine etkisine yönelik görüşleri nelerdir?

2. Ailelerindenden kaynaklanan faktörlerin yükseköğretim programı seçimlerine etkisine yönelik görüşleri nelerdir?

3. Arkadaşlarından kaynaklanan faktörlerin yükseköğretim programı seçimlerine etkisine yönelik görüşleri nelerdir?

4. Yükseköğretim programlarının mezunlarına sağlayabileceği iş imkânlarının ve maddi kazancın yükseköğretim programı seçimlerine etkisine yönelik görüşleri nelerdir?

5. Üniversitelerin burs, yurt, sosyal aktivite, yurt dışı eğitim (Erasmus vb.) gibi olanaklarının yükseköğretim programı seçimlerine etkisine yönelik görüşleri nelerdir? 
6. Yükseköğretim programlarının toplum üzerindeki imajının, statü ya da saygınlığının yükseköğretim programı seçimine etkisine yönelik görüşleri nelerdir?

7. Yükseköğretim programının ve bağlı olduğu üniversitenin akademik kadrosunun yükseköğretim programı seçimlerine etkisine yönelik görüşleri nelerdir?

8. Üniversitenin bulunduğu şehrin yükseköğretim programı seçimlerine etkisine yönelik görüşleri nelerdir?

9. Özel üniversitelerin programlarının tercih edilme durumlarının yükseköğretim programı seçimlerine etkisine yönelik görüşleri nelerdir?

10. Öğretmenlik programlarının tercih edilme durumlarının yükseköğretim programı seçimlerine etkisine yönelik görüşleri nelerdir?

11. Farklı lise türlerinde (Anadolu Lisesi, Anadolu İmam Hatip Lisesi, Mesleki ve teknik lise, Fen lisesi) öğrenim görmeleri yükseköğretim program tercihleri arasındaki farklılığa neden olmakta mıdır?

12. Yükseköğretim programlarına öğrenci seçme sistemine yönelik olumlu, olumsuz düşünceleri ve önerileri nelerdir?

\section{Yöntem}

\section{Araştırmanın Modeli}

On ikinci sınıf öğrencilerinin yükseköğretim programı seçimlerini etkileyen faktörleri ve öğretmenlik programlarını tercih etme durumlarını incelemeyi amaçlayan bu araştırma olgubilim deseninde nitel bir çalışmadır. Olgular yaşadığımız dünyada olaylar, deneyimler, durumlar, kavramlar, algılar ve yönelimler gibi çeşitli biçimlerde karşımıza çıkabilmektedir (Yıldırım ve Şimşek, 2015). Araştırmada ele alınan olgu, öğrencilerin meslek seçimlerini etkileyen faktörler ve öğretmenlik mesleğini tercih etme durumlarıdır. Araştırmada bu doğrultuda nitel araştırma yöntemlerinden görüşme yöntemi kullanılmıştır. Görüşme yöntemi nitel araştırmalarda bilgi toplamak için en çok kullanılan yön- 
temlerden birisidir. Bir konuda düşüncesi alınacak kişi ya da kişilerle bireysel ya da grup halinde yürütülen, yüz yüze yapılan ve sözel sorulara sözel yanıtların verildiği veri toplama yöntemidir (Merriam, 2013).

\section{Araştırmanın Örneklemi}

$\mathrm{Bu}$ araştırmanın örneklemini 2017-2018 eğitim-öğretim yılında Kahramanmaraş ilinin Dulkadiroğlu ve Onikişubat ilçelerinde bulunan ve dört farklı lise türünün on ikinci sınıfında öğrenim gören 100 öğrenci oluşturmaktadır. Olgubilim deseninde hazırlanan bu araştırmada, örneklemin seçimi amaçlı örnekleme yöntemlerinden maksimum çeşitlilik örneklemesine uygun olarak gerçekleştirilmiştir. Buradaki amaç, örneklemde yer alan ve çalışılan problemle ilgili bireylerin çeşitliliğini maksimum derecede yansıtmaktır (Yıldırım ve Şimşek, 2015). Örneklemi oluşturan öğrencilerin okul türlerine göre dağılımında; Anadolu Liseleri'nden \%40, Mesleki ve Teknik Anadolu Liseleri'nden \%30, Anadolu İmam Hatip Liseleri'nden \%20 ve Fen Liseleri'nden \%10 oranında öğrenci örnekleme dahil edilerek örneklemin maksimum çeşitliliğe dayalı olması sağlanmaya çalışılmıştır.

\section{Veri Toplama Aracı}

On ikinci sınıf öğrencilerinin yükseköğretim programı seçimlerini etkileyen faktörleri ve öğretmenlik programlarını tercih etme durumlarını incelemeyi amaçlayan bu araştırmada veri toplama aracı olarak kişisel bilgi formu ve yarı yapılandırılmış görüşme formu kullanılmıştır. Nitel çalışmalar yapan çoğu araştırmacılar veri toplamak amacıyla çeşitli tekniklere başvurmaktadır (Glesne, 2013). Bu çalışmada veri toplama aracı olarak kullanılan yarı yapılandırılmış görüşme formu hazırlandıktan sonra üç öğrenciyle pilot çalışma gerçekleştirilmiştir. Pilot çalışma sonrasında bir eğitim uzmanı, iki rehber öğretmen ve bir branş öğretmeniyle görüşme formunun kapsam, yapı ve dil geçerliği değerlendirilmiştir. Bu değerlendirme neticesinde son şekli belirlenen görüşme formunda, öğrencilerin yükseköğretim programı seçimlerini etkileyen faktörleri ve öğretmenlik programlarını tercih etme durumlarını belirlemeye yönelik açı uçlu 12 soru yer almaktadır. 


\section{Verilerin Toplanması, Çözümlenmesi ve Güvenirliği}

Maksimum çeşitlilik örneklemesine dayalı olarak okullar belirlendikten sonra, her okulun genel programına ve on ikinci sınıf öğrencilerinin ders programına uygun olarak öğrencilerden gerekli randevular alınmış, 2018 yılı Mart ve Haziran ayları içerisinde veriler toplanmıştır. Görüşmeler, araştırmacılardan biri tarafından çalışmaya katılan her öğrenciyle bireysel ve yüz yüze gerçekleştirilmiştir. Veriler, görüşmeleri etkilemeyecek şekilde okullarda uygun görülen ortamlarda toplanmıştır. Çalışmaya katılan öğrencilere, görüşme sırasında ses kaydı ve araştırmacının not alması şeklinde iki yöntemin kullanıldığı açıklanarak, öğrencilerin taleplerine göre ses kaydı veya not alma yoluyla çalışma sürdürülmüştür. Görüşmeler her bir öğrenciyle ortalama 15-20 dakika aralığında gerçekleştirilmiştir. Görüşmeler tamamlandıktan sonra ses kaydı yoluyla yapılan görüşmeler eksiksiz olarak metin haline dönüştürülmüş ve araştırmadan elde edilen tüm verilerin çözümlenmesinde içerik analizi yöntemi kullanılmıştır. İçerik analizi sonucunda kodlara ve temalara ulaşılmıştır. Araştırmanın her sorusu için belirlenen temalar ve ulaşılan kodlar tablolar haline dönüştürülmüştür. Ayrıca bulguların daha açık ve anlaşılır olması amacıyla doğrudan alıntılara yer verilmiştir. Kodlayıcılar arasındaki benzerlik oranı verilerin güvenirliğinin bir göstergesi olduğundan (Baltacl, 2017), görüşme formu ile elde edilen verilerin güvenirlik analizi için Miles ve Huberman'ın (1994) güvenirlik analizi formülünden yararlanılmıştır: Araştırmacı ve görüşü alınan uzman, görüşme verileri üzerinde 402 kod ile görüş birliği sağlarken, 24 kodda ise görüş ayrıllğı yaşamışlardır. Elde edilen kod sayıları formülde yerine konulduğunda kodlayıcı güvenirliği .94 olarak hesaplandığından, verilerin güvenilir olduğuna karar verilmiştir.

\section{Bulgular}

On ikinci sınıf öğrencilerinin kişisel özellikleri, yetenek ve ilgi alanlarının yükseköğretim programı seçimlerine etkisine ilişkin bulgulara Tablo 1'de yer verilmiştir. 
Tablo 1. On ikinci sını öğrencilerinin kişisel özellikleri, yetenek ve ilgi alanlarının yükseköğretim programı seçimlerine etkisine ilişkin bulgular

\begin{tabular}{|c|c|c|c|}
\hline Tema & Kodlar & Frekans & Programlar \\
\hline \multirow{31}{*}{ Bireysel özellikler etkili } & Adaletli olma & 11 & Hukuk \\
\hline & Dil öğrenme & 9 & İngilizce Öğrt. \\
\hline & Sportif beceriler & 8 & Beden Eğt.Öğr. \\
\hline & Gözlem becerisi & 7 & Makine Müh. \\
\hline & Fiziksel yap1 & 6 & Polis MYO \\
\hline & Liderlik & 5 & Milli Savunma \\
\hline & Canlılara ilgi & 5 & Tıp Fakültesi \\
\hline & Tamir yapma & 5 & Elk.Elkt. Müh. \\
\hline & Yardim etme & 4 & Tıp Fakültesi \\
\hline & Dini duygular & 4 & İlahiyat Fak. \\
\hline & Maket yapma & 3 & Diş Hekimliği \\
\hline & Mutfak becerileri & 2 & Turizm Otel. \\
\hline & Baristalık & 2 & Turizm Otel. \\
\hline & Bilgisayar becerisi & 2 & Bilgisayar Müh. \\
\hline & İnşaat ilgisi & 2 & İnşaat Müh. \\
\hline & Çizim Yapma & 2 & Mimarlık \\
\hline & İletişim becerisi & 2 & Hemşirelik \\
\hline & Dinlemeyi sevme & 2 & PDR \\
\hline & Yalnız kalma & 1 & Yazılım Müh. \\
\hline & İkna Edebilme & 1 & Beslenme Diyet. \\
\hline & İletişim becerisi & 1 & Psikoloji \\
\hline & Kararlılık & 1 & Genetik Müh. \\
\hline & Çocukları sevme & 1 & Sınıf Öğrt. \\
\hline & Müzik dinleme & 1 & Müzik Öğrt. \\
\hline & Ticari özgeçmiş & 1 & Pazarlama \\
\hline & Girişimcilik & 1 & Uz. Hav. Müh. \\
\hline & Sabirlı olma & 1 & Sınıf Öğgrt. \\
\hline & Resim yapma & 1 & Resim Öğrt. \\
\hline & Şiir yazma & 1 & Türkçe Öğrt. \\
\hline & Araba parçaları & 1 & Otomotiv Öğrt. \\
\hline & Sert Mizaç & 1 & Adalet MYO \\
\hline \multirow{5}{*}{ Bireysel özellikler etkisiz } & Yeteneksizlik & 1 & İktisat \\
\hline & İş kaygısı & 1 & \\
\hline & Maddi rahatlık & 1 & Program \\
\hline & Puan kaygısı & 1 & Belirtilmedi \\
\hline & Özgüven eksikliği & 1 & \\
\hline
\end{tabular}

Tablo 1' de görüldüğü gibi bireysel özelliklerin etkisi temasında araştırmaya katılan on ikinci sınıf öğrencilerinin tamamına yakını (95/100) kişisel özelliklerinin, yeteneklerinin ve ilgi alanlarının yükseköğretim programı seçimlerini etkileyeceğini düşünmektedir. Böyle düşünenler 
arasında en çok (11/100) adalet duygularının daha baskın olması nedeniyle "Hukuk" programin tercih edecek olanlar yer almaktadır. Ayrica, yabancı dil öğrenmeye olan ilgi nedeniyle "İngilizce Öğretmenliği" programın (9/100), sportif becerileri nedeniyle "Beden Ĕ̆itimi Öğretmenliği" programını tercih edecek öğrenciler de bulunmaktadır. Bu öğrencilerden bazılarının görüşleri aşağıdaki gibidir:

- "Haksızlık karşısında dayanamıyorum ve adil olanı hemen uygulamak istiyorum." (Hukuk)

- "Ingilizce öğrenmekten çok hoşlanıyorum, ayn zamanda farklı bir kültürü de öğretiyor. Bu nedenle İngilizce öğretmeni olmak istiyorum." (İngilizce öğretmenliği)

Bireysel özelliklerin etkisiz olduğu temasında ise on ikinci sınıf öğrencilerden bir kısmı (5/100) kişisel özelliklerinin, yetenek ve ilgi alanlarının yükseköğretim programı seçimlerini etkilemeyeceğini düşünmektedir. Böyle düşünen öğrencilerin gerekçeleri arasında; kendini hiçbir alanda yetenekli bulmama, geleceğe yönelik iş bulabilme kaygısının çok yüksek olması, şu an sahip oldukları maddi olanaklarının iyi düzeyde olması gibi faktörler yer almaktadır. Bu öğrencilerden bazılarının görüşleri aşağıdaki gibidir:

- "Kendimi hiçbir alanda yetenekli görmüyorum. Bu nedenle iktisat programin tercih etmeyi düşünüyorum."

- “Önemli olan iş bulabileceğin bir alanda eğitim almak, yeteneklerin iş bulmaya hiçbir katkısı yok."

On ikinci sınıf öğrencilerinin ailelerinden kaynaklanan faktörlerin yükseköğretim programı seçimlerine etkisine ilişkin bulgulara Tablo 2' de yer verilmiştir.

Tablo 2'de görüldüğü gibi ailelerin etkisiz olması temasında araştırmaya katılan on ikinci sınıf öğrencilerin çoğu (67/100) yükseköğretim programı seçimlerinde ailelerinin etkili olmayacağını düşünmektedir. Öğrencilerin böyle düşünme nedenlerinden bazıları ise; geleceğini ilgilendiren bir kararı kişinin kendisinin vermesi gerektiği (23/100), verecekleri kararlara ailelerinin sayg1 duyacağı (15/100), ailelerinin her durumda kendilerine yalnızca destek olacağ 1 (12/100) şeklindedir. Bu öğrencilerden bazılarının görüşleri aşağıdaki gibidir:

- "Benim hayatım ve ben yönlendirmeliyim, erişkin bir bireyim artık on sekiz yaşındayım." 
- "Herkes kendi hayatın yaşayacak, aile üyelerim beni kararımı etkileyemezler."

Tablo 2. On ikinci sinıf öğrencilerinin ailelerinden kaynaklanan faktörlerin yükseköğretim programı seçimlerine etkisine ilişkin bulgular

\begin{tabular}{llr}
\hline Tema & Kodlar & Frekans \\
\hline & Kişisel yaşam & 23 \\
Karara saygı duyma & 15 \\
& Ailenin desteği & 12 \\
Eğitim alma arzusu & 5 \\
& Ailede güven & 5 \\
Öncelikli ilgi alanları & 3 \\
Kararlarda özgürlük & 2 \\
Kişisel sinıra saygı & 2 \\
\hline Ailenin doğruları & 11 \\
& Ebeveyn istekleri & 7 \\
& Tip eğitimi & 4 \\
& Maddi imkanlar & 2 \\
& Öğretmen olma & 2 \\
& Prestij sağlama & 2 \\
& Seçenek sunma & 1 \\
& Hemşire olma & 1 \\
& Şehir seçme & 1 \\
& Cinsiyet faktörü & 1 \\
& Yurtdişı eğitim & 1 \\
\hline
\end{tabular}

Ailelerin etkileri temasında öğrencilerinden bazıları (33/100) yükseköğretim programı seçimlerinde ailelerinin etkili olacağını düşünmektedir. Öğrencilerin böyle düşünme nedenleri arasında ise; her konuda en doğru kararı yalnızca ailelerinin verebileceği (11/100) inancı, ailenin kültürel yapısında babanın isteklerinin daha ön planda olması (7/100) yer almaktadır. Bu öğrencilerden bazılarının görüşleri aşağıdaki gibidir:

- "Babamın istekleri önemli, benim için gelecekte iyi olanı o daha iyi bilir."

- "Zaten şu an okuduğum bölüme de babamın zoruyla geldim, yine onlar ne isterse onu seçeceğim."

On ikinci sınıf öğrencilerinin arkadaşlarından kaynaklanan faktörlerin yükseköğretim programı seçimlerine etkisine ilişkin bulgulara Tablo 3'te yer verilmiştir. 
Tablo 3. On ikinci sınıf öğrencilerinin arkadaşlarından kaynaklanan faktörlerin yükseköğretim programı seçimlerine etkisine ilişkin bulgular

\begin{tabular}{llr}
\hline Tema & Kodlar & Frekans \\
\hline & Kararlı olma & 27 \\
Kişisel yaşam & 13 \\
İlgi alanı & 6 \\
Arkadaşlık ilişkileri & 6 \\
Umursamazlık & 5 \\
& Ailenin önceliği & 4 \\
Özgürlük & 4 \\
Arkadaşlar etkisiz & Saygı duyma & 4 \\
& Güven duymama & 2 \\
& Hedefe odaklanma & 2 \\
& Arkadaş vizyonu & 2 \\
& Tecrübesizlik & 1 \\
& Kapasite yetersizliği & 1 \\
& İş önceliği & 1 \\
\hline Aynı şehir & 8 \\
& Motivasyon & 5 \\
Arkadaşlar etkili & Mantıklı bulma & 2 \\
& Zeki olma & 2 \\
& Kı arkadaş & 2 \\
& Kararsizlı & 1 \\
& Arkadaşlık bağları & 1 \\
& Aynı program & 1 \\
\hline
\end{tabular}

Tablo 3'te görüldüğü gibi arkadaşları etkisiz bulma temasında araştırmaya katılan on ikinci sınıf öğrencilerinin çoğu (78/100) yükseköğretim programı seçimlerinde arkadaşlarının etkili olmayacağ 1 görüşündedir. Öğrencilerin böyle düşünme nedenleri arasında; kendilerini kararlı bulmaları (27/100), bu seçiminin yalnızca kişisel yaşamlarını ilgilendirdiği düşüncesi (13/100), ilgi duyulan ve yetenekli olduğuna inanılan alanda eğitim alma isteği (6/100) ve seçimlerini etkileyebilecek samimi arkadaşlık bağlarının olmaması (6/100) gibi etkenler yer almaktadır. Bu öğrencilerden bazılarının görüşleri aşağıdaki gibidir.

- "Kendi kararlarımı ben verebilecek kadar büyüdüm, arkadaşım dahi olsa beni etkileyemez."

- "Herkes kendi hayatını yaşar, karalarımda sonuçları da beni ilgilendirir." Arkadaşların etkisine yönelik olarak öğrencilerden bazıları (22/100) ise yükseköğretim programı seçimlerinde arkadaşlarının etkili olacağını 
düşünmektedir. Öğrencilerin böyle düşünme nedenleri arasında; arkadaşlarıyla aynı şehirdeki üniversitede okumak (8/100), arkadaşlarının olumlu motivasyon sağlamalarında katkısının olacağı (5/100) gibi etkenler yer almaktadır. Bu öğrencilerden bazılarının görüşleri aşağıdaki gibidir:

- "Sevdiğim arkadaşlarımla aynı üniversiteyi kazanırsam eğer farklı bölümlerde okusak da ev tutup bir arada kalmak istiyoruz, bence çok eğlenceli bir üniversite hayatımız olur."

- "Arkadaşlarım beni motive ediyor, onlarla vakit geçirmeyi çok seviyorum."

On ikinci sınıf öğrencilerinin yükseköğretim programlarının mezunlarına sağlayabileceği iş imkanlarının ve maddi kazancın yükseköğretim programı seçimlerine etkisine ilişkin bulgulara Tablo 4' de yer verilmiştir. Tablo 4 'te görüldüğü gibi iş ve kazancın etkileri temasında on ikinci sınıf öğrencilerinin çoğu (70/100) yükseköğretim programlarının mezunlarına sağlayacağı iş imkânı ve maddi kazancın yükseköğretim programı seçimlerinde etkili olacağını düşünmektedir. Öğrencilerin kendilerine iş ve maddi kazanç sağlayacağını düşündükleri yükseköğretim programlarından en fazla öne çıkanlar ve tercih edilme nedenleri şunlardır: Adalet alanında ihtiyacın fazla olmasından dolayı Hukuk Fakültesi (9/100), maddi kazancinın fazla olması nedeniyle Tip Fakülteleri (8/100), teknolojinin gelişmesiyle birlikte makinelerin artması ve iş alanının çok olmasıyla Makine Mühendisliği (6/100), devlet kurumları dışında da çalışma alanlarının bulunmasıyla İngilizce öğretmenliği (6/100) ve Beden Eğitimi Öğretmenliği, Milli Savunma Üniversitesi'nde (3/100) okunacak her programın devlet işi garantili olması oluşturmaktadır. Bu öğrencilerden bazılarının görüşleri aşağıdaki gibidir:

- “Neden önü kapalı bir programa gideyim ki, akrabam Edebiyat Öğretmenliği'ni bitirdi ve KPSS'den doksan üzerinde bir puan aldı ancak atanamadı ve şu an çobanlik yapıyor."

- "Mezun olunca kolay iş bulmak ve çok para kazanmak için Tıp istiyorum."

İş ve kazancın etkisizliği temasında ise öğrencilerden bazıları (30/100) bir yükseköğretim programının mezunlarına sağlayabileceği iş imkânı ve maddi kazancının yükseköğretim programı seçimlerinde etkili olmayacağını düşünmektedir. 
Tablo 4. On ikinci sını öğrencilerinin yükseköğretim programlarının mezunlarına sağlayabileceği iş imkanlarının ve maddi kazancın yükseköğretim programı seçimlerine etkisine ilişkin bulgular

\begin{tabular}{|c|c|c|}
\hline Tema & Programlar & Frekans \\
\hline \multirow{28}{*}{ İş ve kazanç etkili } & Hukuk & 9 \\
\hline & Tip & 8 \\
\hline & İngilizce Öğretmenliği & 6 \\
\hline & Makine Mühendisliği & 6 \\
\hline & Beden Eğitimi Öğretmenliği & 4 \\
\hline & Milli Savunma Üniversitesi & 3 \\
\hline & Elektrik-Elektronik Müh. & 3 \\
\hline & İlahiyat Fakültesi & 3 \\
\hline & Polis Meslek Yüksekokulu & 2 \\
\hline & Diş Hekimliği & 2 \\
\hline & Turizm ve Otelcilik & 2 \\
\hline & Yazılım Mühendisliği & 2 \\
\hline & Bilgisayar Mühendisliği & 2 \\
\hline & İnşaat Mühendisliği & 2 \\
\hline & Mimarlık & 2 \\
\hline & Hemşirelik & 2 \\
\hline & PDR & 1 \\
\hline & Sınıf Öğretmenliği & 1 \\
\hline & Beslenme ve Diyetetik & 1 \\
\hline & Psikoloji & 1 \\
\hline & Genetik Mühendisliği & 1 \\
\hline & Müzik Öğretmenliği & 1 \\
\hline & Pazarlama & 1 \\
\hline & Uzay ve Havacılık Müh. & 1 \\
\hline & Resim Öğretmenliği & 1 \\
\hline & Türkçe Öğretmenliği & 1 \\
\hline & Otomotiv Öğretmenliği & 1 \\
\hline & Adalet MYO. & 1 \\
\hline \multirow{10}{*}{ İş ve kazanç etkisiz } & Severek yapma & 9 \\
\hline & Manevi doyum & 5 \\
\hline & Mutlu olma & 4 \\
\hline & İtibar kazanma & 2 \\
\hline & Bilişsel doyum & 2 \\
\hline & Yeteneklerle uyumlu & 2 \\
\hline & Kendini geliştirme & 2 \\
\hline & Ahlaklı olma & 2 \\
\hline & Faydalı olma & 1 \\
\hline & Vatana hizmet & 1 \\
\hline
\end{tabular}

Öğrencilerin böyle düşünme nedenleri arasında; bir mesleği severek, isteyerek yapmanın paradan daha önemli görülmesi (9/100), hangi iş ya 
da ne kadar kazancın değil, manevi doyumun sağlanmasının değerli bulunması (5/100), mutlu bir insan olarak yaşamanın maddi güçten ve iş bulmaktan daha değerli algılanması (4/100) gibi faktörler yer almaktadır. $\mathrm{Bu}$ öğrencilerden bazılarının görüşleri aşağıdaki gibidir:

- "Parayı hiç düşünmüyorum, isterse ayda on bin lira versinler, önemli olan severek bir işi yapmam."

- "Severek yapabileceğim bir iş olsun, ömrümün sonuna kadar yaparım."

- "Ölümlü bir dünyada yaşıyoruz ve ölümlü insanları. Bu nedenle manevi doyum daha önemli benim için."

On ikinci sınıf öğrencilerinin, üniversitelerin burs, yurt, sosyal aktivite, yurt dışı eğitim (Erasmus vb.) gibi olanaklarının yükseköğretim programı seçimlerine etkisine ilişkin bulgulara Tablo 5'de yer verilmiştir.

Tablo 5'te görüldüğü gibi üniversite olanakları temasında araştırmaya katılan on ikinci sınıf öğrencilerinin çoğu (81/90) yükseköğretim programı seçimlerinde üniversitelerin burs, yurt, sosyal aktivite, yurt dışı eğitim vb. olanaklarının etkili olacağını düşünmektedir.

Tablo 5'te görüldüğü gibi, öğrencilerin seçimlerini etkileyecek üniversite olanaklardan bazılarını ise; yurt dışında dil öğrenme isteği, farklı kültürleri daha yakından tanıma, nitelikli bir eğitim özgeçmişine sahip olma, iş imkanı, Arapça öğrenme, vizyon kazanma gibi faktörlere bağlı olarak Erasmus (28/100), maddi koşulların yetersizliği, daha konforlu bir üniversite hayatı geçirebilme, öğrencinin paraya ihtiyacının her zaman olacağı kanaati ve kaynaklar alıp kendini geliştirebilme gerekçeleriyle burs (18/100), daha rahat yaşamak, kendini güvende hissetmek ve üniversiteye kolay ulaşımı sağlamak gibi etkenler nedeniyle yurt (12/100), toplumda sosyalleşebilmek, farklı yerleri gezerek kendini geliştirmek, kültür seviyesini yükseltebilmek gibi faktörlere bağlı olarak gezi programları (11/100) oluşturmaktadır. Bu öğrencilerden bazılarının görüşleri aşağıdaki gibidir:

- "Yurtdışına gitmek istiyorum. Hem birçok yabancı insan tanırım, hem de yabancı dilimi ilerletir ilerde orada çalışmayı bile düşünebilirim."

- "Babamin işi yok köyde oturuyoruz, hayvanlarımız var, bunlar da benim ihtiyaçlarımı karşılamaya yetmez. Bu nedenle burs alabilmek benim için oldukça önemli olacak." 
Tablo 5. On ikinci sını öğrencilerinin üniversitelerin burs, yurt, sosyal aktivite, yurt dışı eğitim (Erasmus vb.) gibi olanaklarının yükseköğretim programı seçimlerine etkisine ilişskin bulgular

\begin{tabular}{|c|c|c|c|}
\hline Tema & Olanaklar & Kodlar & Frekans \\
\hline \multirow{32}{*}{ Olanaklar önemli } & Erasmus & Dil öğrenme & 9 \\
\hline & Burs & Maddi imkanlar & 8 \\
\hline & Erasmus & Kültürleri öğrenme & 4 \\
\hline & Burs & Rahat yaşam & 4 \\
\hline & Burs & Öğrenci hayatı & 4 \\
\hline & Gezi & Sosyalleşme & 4 \\
\hline & Erasmus & Nitelikli eğitim & 3 \\
\hline & Erasmus & İş imkânı & 3 \\
\hline & Yurt & Rahat yaşam & 3 \\
\hline & Yurt & Güvende olma & 3 \\
\hline & Yurt & Ulaşım kolaylı̆̆ı & 3 \\
\hline & Gezi & Kendini geliştirme & 3 \\
\hline & Sportif etkinlik & Sporu sevme & 3 \\
\hline & Erasmus & Arapça öğrenme & 2 \\
\hline & Erasmus & Vizyon sağlama & 2 \\
\hline & Yurt & Maddi şartlar & 2 \\
\hline & Gezi & Yaşam kalitesi & 2 \\
\hline & Gezi & Kültürlenme & 2 \\
\hline & Bilimsel çalışma & Grup toplantıları & 2 \\
\hline & Sosyal kulüp & Eğlenmeyi sevme & 2 \\
\hline & Sosyal kulüp & Rol oynama & 2 \\
\hline & Erasmus & Tecrübe kazanma & 1 \\
\hline & Erasmus & İletişim kurma & 1 \\
\hline & Erasmus & Nitelikli özgeçmiş & 1 \\
\hline & Erasmus & Makale okuma & 1 \\
\hline & Erasmus & Güncel bilgiler & 1 \\
\hline & Burs & Kendini geliştirme & 1 \\
\hline & Burs & Sosyalleşme & 1 \\
\hline & Yurt & Tecrübe kazanma & 1 \\
\hline & Bilimsel çalışma & AR-GE çalışması & 1 \\
\hline & Sportif etkinlik & Futbol oynama & 1 \\
\hline & Sosyal kulüp & Yardımlaşma & 1 \\
\hline \multirow{6}{*}{$\begin{array}{l}\text { Olanaklar } \\
\text { önemsiz }\end{array}$} & & Hedeflenen program & 6 \\
\hline & & Kaliteli eğitim & 4 \\
\hline & & İmkanlarla yetinme & 4 \\
\hline & & İş imkânı & 3 \\
\hline & & Şehir önyarg1sı & 1 \\
\hline & & İlgi duymama & 1 \\
\hline
\end{tabular}

Olanakların önemsizliği temasında öğrencilerden bazıları (19/100) yükseköğretim programı seçimlerinde üniversitelerin burs, yurt, sosyal 
aktivite, yurt dışı eğitim gibi olanaklarının etkili olmayacağını düşünmektedir. Öğrencilerin böyle düşünme nedenlerinden bazılarını ise; hedeflenen bölümü kazanıp okumanın daha çok önemsenmesi (6/100), önceliğin üniversitenin eğitiminin nitelikli ve kaliteli olmasına verilmesi (4/100) gibi etkenler oluşturmaktadır. Bu öğrencilerden bazılarının görüşleri aşağıdaki gibidir:

- "Üniversitede ne olduğu önemli değil, önemli olan kazanmayı hedeflediğim programda eğitim almak."

- "Üniversitenin verdiği eğitimin kalitesi olanaklarmdan daha önemli bence."

On ikinci sınıf öğrencilerinin yükseköğretim programlarının toplum üzerindeki imajı, statü ya da saygınlığının yükseköğretim program seçimlerine etkisine yönelik bulgular Tablo 6 'da verilmiştir.

Tablo $6^{\prime}$ da görüldüğü gibi statünün etkileri temasında araştırmaya katılan on ikinci sınıf öğrencilerinin yarısından fazlası (65/100) yükseköğretim programlarının toplum üzerindeki imajı, statü ya da saygınlı̆̆ının yükseköğretim programı seçimlerinde etkili olacağını düşünmektedir. Böyle düşünen öğrencilerin toplumsal kazanımlarından en fazlasını özgüveni olan bir birey olmak (10/100), toplumda saygın bir insan haline gelmek (9/100), mutlu bir birey olmak (5/100), bulunduğu konumla gurur duymak (4/100), değerli bir insan olduğunu hissetmek $(4 / 100)$ oluşturmaktadır. Bu öğrencilerden bazılarının görüşleri aşağıdaki gibidir:

- “Annemin bir ortama girdiğinde benim oğlum okudu mühendis oldu ya da doktor oldu demesi var. Annemin ezilmesini istemem. Mesela biz şimdi motor bölümünde okuyoruz. Ancak toplum, çeore bizim motor bölümünü, sanayi eşrafını hor görüyorlar, tepeden bakıyorlar."

- "Akrabalarımdan biri doktor ve bir ortama geldiğinde büyükler bile kalkıp ona selam veriyor. Makam olunca insana insan muamelesi yapiliyor."

Statünün önemsizliği temasında öğrencilerden bazıları ise $(35 / 100)$ yükseköğretim programlarının toplum üzerindeki imajı, statü ya da saygınlığının yükseköğretim programı seçimlerinde etkili olmayacağını düşünmektedir. 
Tablo 6. On ikinci sınıf öğrencilerinin yükseköğretim programlarının toplum üzerindeki imajı, statü ya da saygınlı̆̆ının yükseköğretim program seçimlerine etkisine yönelik bulgular

\begin{tabular}{|c|c|c|}
\hline Tema & Kodlar & Frekans \\
\hline \multirow{23}{*}{ Statü önemli } & Özgüven duyma & 10 \\
\hline & Saygınlık kazanma & 9 \\
\hline & Mutlu olma & 5 \\
\hline & Gurur duyma & 4 \\
\hline & Değerli olma & 4 \\
\hline & Ego artış1 & 3 \\
\hline & Üstün olma & 3 \\
\hline & Tanınma & 3 \\
\hline & Aile saygınlığ1 & 3 \\
\hline & Emir verme & 2 \\
\hline & Kariyer yapma & 2 \\
\hline & Makam edinme & 2 \\
\hline & Kültürlenme & 2 \\
\hline & Kimlik kazanma & 2 \\
\hline & Ağırbaşlı olma & 2 \\
\hline & Otorite olma & 2 \\
\hline & Öğretmen olma & 1 \\
\hline & Geniş vizyon & 1 \\
\hline & Maddi güç & 1 \\
\hline & Din adamı olma & 1 \\
\hline & Milli duygular & 1 \\
\hline & Verimli çalışma & 1 \\
\hline & Hayranlık uyandırma & 1 \\
\hline \multirow{14}{*}{ Statü önemsiz } & Kişisel istekler & 7 \\
\hline & Severek yapma & 5 \\
\hline & Fayda sağlama & 5 \\
\hline & İnsani değerler & 3 \\
\hline & Mutlu olma & 2 \\
\hline & Hayale ulaşma & 2 \\
\hline & Ruhsal doyum & 2 \\
\hline & Karakterli olma & 2 \\
\hline & Hedefe ulaşma & 2 \\
\hline & Zamana birakma & 1 \\
\hline & Öğretmenlik mesleği & 1 \\
\hline & Yön verme & 1 \\
\hline & Milli duygular & 1 \\
\hline & Umursamaz olma & 1 \\
\hline
\end{tabular}

Öğrencilerin böyle düşünme nedenlerinden bazılarını ise; bir programın statü, saygınlık gibi faktörlere bağlı olarak tercih etmenin doğru 
bulunmaması, kişinin isteklerini gerçekleştirmesinin daha doğru bir seçim olacağ $(7 / 100)$, istenilen programın ve mesleğin sevildiği için tercih edilmesi gerektiği (5/100), topluma fayda sağlayacak, çalışmalar yapmanın daha önemli olması (5/100) oluşturmaktadır. Bu öğrencilerden bazılarının görüşleri aşağıdaki gibidir:

- "Başkasının övgüsüne layık olmak için üniversite okumam. Bin kere daha gelsem bu dünyaya mutlu olmak için okurum."

- "Dünyada insan olabilmek ve insan olarak hayatın sürdürebilmek, hiçbir makamın karşılayamayacağı bir duygudur."

On ikinci sınıf öğrencilerinin yükseköğretim programının ve bağlı olduğu üniversitenin akademik kadrosunun yükseköğretim programı seçimlerine etkisine yönelik bulgular Tablo 7'de verilmiştir.

Tablo 7'de görüldüğü gibi aranan nitelikler temasında araştırmaya katılan on ikinci sınıf öğrencilerinin çoğu (77/100) bir yükseköğretim programının ve bağlı olduğu üniversitenin akademik kadrosunun seçimlerinde etkili olacağını düşünmektedir. Böyle düşünen öğrencilerin akademik kadroda en fazla aradıkları niteliklerden bazıları; öğretim üyelerinin alanında bilgili, donanımlı olması (10/100) belirli bir tecrübeye sahip olması (7/100) bilgileri öğrencinin seviyesine uygun anlatabilmesi (6/100), cana yakın bir karaktere sahip olması (6/100), kadronun çoğunluğunu profesörlerin oluşturması (5/100), bilimsel çalışmalarla başarısını kanıtlamış olmasıdır (5/100). Bu öğrencilerden bazılarının görüşleri aşağıdaki gibidir:

- "Hocalarm bilgi birikimi beni etkiler. Eski ve güçlü kadrosu olan üniversiteleri tercih ederim. Yeni, zayıf, doçent sıkıntısı olan yerleri tercih etmem."

- "Ben üniversite tercihi yapacă̆ım zaman üniversitenin web sayfasından akademisyen kadrosuna bakıp ona göre tercih yapacağım. Ĕ̆er kadroda yaşlı hocalar varsa benim için idealdir. Çünkü daha tecrübeli olur."

Niteliklerin önemsizliği temasında öğrencilerden bazıları (23/100) yükseköğretim programının ve bağlı olduğu üniversitenin akademik kadrosunun yükseköğretim programı seçimlerinde etkili olmayacağını düşünmektedir. 
Tablo 7. On ikinci sını öğrencilerinin yükseköğretim programının ve bağlı olduğu üniversitenin akademik kadrosunun yükseköğretim program seçimlerine etkisine yönelik bulgular

\begin{tabular}{|c|c|c|}
\hline Tema & Kodlar & Frekans \\
\hline \multirow[t]{24}{*}{ Akademik kadro önemli } & Bilgili & 10 \\
\hline & Tecrübeli & 7 \\
\hline & Öğretici & 6 \\
\hline & Cana yakın & 6 \\
\hline & Profesör & 5 \\
\hline & Başarılı & 5 \\
\hline & Zorlamayan & 4 \\
\hline & İleri görüşlü & 3 \\
\hline & Yönlendirici & 3 \\
\hline & İlgili & 3 \\
\hline & Tanınmış & 3 \\
\hline & Vicdanlı & 3 \\
\hline & Yaşlı & 2 \\
\hline & Önyargisız & 2 \\
\hline & Adaletli & 2 \\
\hline & Kişilikli & 2 \\
\hline & Nitelikli & 2 \\
\hline & Alanında uzman & 2 \\
\hline & Uyumlu & 2 \\
\hline & Örnek insan & 1 \\
\hline & Mantıklı & 1 \\
\hline & Diksiyonu düzgün & 1 \\
\hline & Eğlenceli & 1 \\
\hline & İyi niyetli & 1 \\
\hline \multirow[t]{10}{*}{ Akademik kadro önemsiz } & Eğitimin içeriği & 6 \\
\hline & Üniversitenin tanınmışlığı & 4 \\
\hline & Hedefini kazanma & 3 \\
\hline & Beklentisiz olma & 3 \\
\hline & Üniversite benzerliği & 2 \\
\hline & Bakış açısı & 1 \\
\hline & Üniversite sayısı & 1 \\
\hline & İlgi duymama & 1 \\
\hline & İleri görüşlü olma & 1 \\
\hline & Çalışma prensibi & 1 \\
\hline
\end{tabular}

Öğrencilerin böyle düşünme nedenlerinden en fazlasını üniversitelerde verilen eğitimin içeriğini yeterli bulmaları (6/100) Türkiye'de başarısıyla tanınan, bilinen bir üniversitede eğitim almanın öncelikli bulunması (4/100), hedeflerinde olan programı kazanmayı ve okumayı yeterli bulmaları (3/100), üniversite eğitiminden hiçbir beklentiye sahip 
olmamaları (3/100) oluşturmaktadır. Bu öğrencilerin görüşlerinden bir kısmı aşağıdaki gibidir:

- "Benim için gideceğim üniversitenin hocalarının özelliklerinin bir anlamı yok. Önemli olan üniversitenin bilinen, kaliteli kurumlardan biri olması."

- "Okuyacağım üniversitedeki akademisyenlerin özellikleri tercihlerimde etkili olmaz. Çünkü ben hayat felsefeme göre; her insanın verim alınacak bir yönü olduğuna inananlardanım."

On ikinci sınıf öğrencilerinin üniversitenin bulunduğu şehrin yükseköğretim programı seçimlerine etkisine ilişkin bulgular Tablo 8'de verilmiştir.

Tablo 8'de görüldüğü gibi şehrin etkileri temasında araştırmaya katılan on ikinci sınıf öğrencilerinin çoğu (85/100) yükseköğretim programı seçimlerinde üniversitenin bulunduğu şehrin etkili olacağını düşünmektedir. Bu temada öne çıanlar ise; üniversite okumak istedikleri şehrin; daha rahat yaşamak ve bir çok imkana ulaşmak kazanımıyla büyükşehir olmasına (9/100), maddi olarak rahat bir üniversite hayatı geçirme kazanımıyla öğrenciye uygun, ucuz bir şehir olmasına (8/100), çevre edinme ve sosyalleşmeyi sağlama düşüncesiyle sosyal aktivite açısından zengin bir yer olmasına (8/100), konforlu bir öğrencilik hayatı geçirebilmek için yaşam standartları gelişmiş bir şehir olmasına (7/100), tanıdık insanların olmasının iyi geleceği düşüncesiyle akrabaların olduğu bir şehire (6/100) yer verecekleri şeklindedir. Bu öğrencilerin görüşlerinden bazıları aşağıdaki gibidir:

- “Üniversite okuyacağım yerin insanlarn ileri görüşlü olmalı. Ben Antalya'dan buraya geldim. Orada turistlerle bile çok rahat iletişim kurarken burada normal insanlarla iletişim kuramadım, beni dışladılar."

- "Üniversiteden mezun olduktan sonra çevreye İstanbul Üniversitesi'nde ya da Gazi'de okudum demek var, bir de Kahramanmaraş'ta okudum demek var. Bence büyükşehirde okuduğunu söylemek beni gururlandırır."

Şehrin etkisiz olduğu temasında öğrencilerden bazıları (15/100) yükseköğretim programı seçimlerinde üniversitenin bulunduğu şehrin etkili olmayacağını belirtmişlerdir. 
Tablo 8. On ikinci sınf öğrencilerinin üniversitenin bulunduğu şehrin yükseköğretim programı seçimlerine etkisine yönelik bulgular

\begin{tabular}{|c|c|c|c|}
\hline Tema & Kodlar & Frekans & Kazanımlar \\
\hline \multirow{25}{*}{ Şehir önemli } & Büyükşehir & 9 & Yaşam kolaylı̆̆ı \\
\hline & Ekonomik şartlar & 8 & Maddi rahatlık \\
\hline & Sosyal aktivite & 8 & Sosyalleşme \\
\hline & Yaşam standartları & 7 & Konfor \\
\hline & Tanıdık olma & 6 & Tanıdık sağlama \\
\hline & Deniz bulunma & 6 & Bakış açısı \\
\hline & İnsan kalitesi & 4 & Güvenilir ortam \\
\hline & Kolay ulaşım & 4 & Zaman tasarrufu \\
\hline & Güvenli olma & 3 & Rahat yaşam \\
\hline & Gezi mekanları & 3 & Renkli yaşam \\
\hline & Nüfus azlığı & 2 & Sakin hayat \\
\hline & Eğitim seviyesi & 2 & Kişisel gelişim \\
\hline & İleri görüşlülük & 2 & Özgürlük \\
\hline & Özgür yaşam & 2 & Huzur \\
\hline & Sakin yap1 & 2 & Stressiz hayat \\
\hline & Kültür seviyesi & 2 & Tecrübe \\
\hline & Tanıdık olmayan & 2 & Hayatı öğrenme \\
\hline & Yaşanılan şehir & 2 & Aile yaşamı \\
\hline & Muhafazakâr & 1 & Kişilik gelişimi \\
\hline & İnternet altyapısı & 1 & Rahat iletişim \\
\hline & Eğlenceli & 1 & Hayata bakış \\
\hline & Turistik & 1 & Sosyal yaşam \\
\hline & Siyasi görüş & 1 & Uyumlu yaşam \\
\hline & Ilıman iklim & 1 & Motivasyon \\
\hline & Yurt imkânı & 1 & Maddi katk1 \\
\hline \multirow{9}{*}{ Şehir önemsiz } & Eğitim alma & 4 & \\
\hline & Kaliteli üniversite & 2 & \\
\hline & Hedefe ulaşma & 2 & \\
\hline & Programın türü & 2 & \\
\hline & Farklı şehir & 1 & \\
\hline & Maddi durum & 1 & \\
\hline & Uyumlu kişilik & 1 & \\
\hline & Umursamaz olma & 1 & \\
\hline & Sınav puanı & 1 & \\
\hline
\end{tabular}

Öğrencilerin böyle düşünme nedenlerinden bazılarını ise; üniversite 
eğitim almanın önemli görülmesi (4/100), üniversitenin akademik alandaki başarılarıyla kalitesini ispatlamış olması (2/100) oluşturmaktadır. Bu öğrencilerden bir kısmının görüşleri aşağıdaki gibidir.

- "Maddi durumumuz iyi olmadığından dolayı, okuyacă̆ım üniversite benim için en uygun koşulları sağladıktan sonra hangi şehir olursa gitmeyi düşünüyorum. Zaten annem ve babam bu konuda karar verecekler."

- "Çok uysal, uyumlu bir insantm. Bulunduğum koşullara hemen ayak uydurabiliyorum. Bu nedenle neresi olsa orada yaşarım."

On ikinci sınıf öğrencilerinin özel üniversitelerin programlarına yükseköğretim programı seçimlerinde yer verme durumlarına yönelik bulgulara Tablo 9'da yer verilmiştir.

Tablo 9'da görüldüğü gibi özel üniversiteleri tercih etmeme temasına göre, araştırmaya katılan on ikinci sınıf öğrencilerinin çoğu (79/100) özel üniversitelerin programlarına yükseköğretim programı seçimlerinde yer vermeyi düşünmemektedir. Öğrencilerin tercih etmeme nedenleri arasında, ailelerinin maddi imkanlarının, ekonomik koşullarının yetersiz olması (54/100), belirli sayıda dersten kalındığında bursun kesileceği (4/100), özelde okumanın "kendim başardım" duygusu oluşturamayacağ1 (4/100) düşünceleri yer almaktadır. Bu öğrencilerden bazılarının görüşleri aşağıdaki gibidir:

- "Biz maddi olarak çok iyi şartlara sahip değiliz. Ailemin durumu zaten yok, onları bir de özel üniversite yazarak zorlamak istemem."

- "Özel üniversiteleri kazanan öğrencilerin çoğuna insanlar ön yargıyla bakıyor. Bu, zengin, bilgisiz, kafası çalısmıyor da ancak baba parasıyla üniversite okumaya çalışıyor diye."

Tercih nedenleri temasında öğrencilerden bazıları (21/100) ise yükseköğretim programı seçimlerinde özel üniversitelerin programlarına yer vereceklerini belirtmişlerdir. Bu öğrencilerden bazıları (6/100) burs kazanabildikleri durumda özel üniversiteleri tercih edeceklerini belirtmişlerdir.

Bir öğrenci Aydın üniversitesi Hukuk Fakültesi, iki öğrenci Yeditepe üniversitesi Tıp Fakültesi, başka bir öğrenci Hasan Kalyoncu üniversitesi İngilizce Öğretmenliği, üniversiteye henüz karar vermemiş öğrencilerden biri Tıp Fakültesi, diğeri ise Psikolojik Danışmanlık ve Rehberlik programına seçimlerinde yer vereceklerini belirtmişlerdir. 
Tablo 9. On ikinci sınıf öğrencilerinin özel üniversitelerin programlarına yükseköğretim programı seçimlerinde yer verme durumlarına yönelik bulgular

\begin{tabular}{|c|c|c|c|}
\hline Tema & Kodlar & Frekans & Üniversite-Program \\
\hline \multirow{13}{*}{$\underline{\text { Tercih etmeme }}$} & Maddi imkanlar & 54 & - \\
\hline & Burs kesilmesi & 4 & - \\
\hline & Başarı duygusu & 4 & - \\
\hline & Devlet imkanları & 4 & - \\
\hline & Polis olma & 2 & - \\
\hline & Paralı eğitim & 2 & - \\
\hline & Samimiyetsizlik & 2 & - \\
\hline & Devlet kalitesi & 2 & - \\
\hline & Para tuzağ1 & 1 & - \\
\hline & Mantıksız bulma & 1 & - \\
\hline & Reklam amaçlı & 1 & - \\
\hline & Önyargılı olma & 1 & - \\
\hline & $\begin{array}{l}\text { Arkadaş } \\
\text { bulamama }\end{array}$ & 1 & - \\
\hline \multirow{19}{*}{$\underline{\text { Tercih nedenleri }}$} & Burs kazanma & 6 & Aydın-Hukuk \\
\hline & & & Yeditepe-Tip \\
\hline & & & Belirsiz-Tip \\
\hline & & & H. Kalyoncu-İngilizce Öğr. \\
\hline & & & Belirsiz-PDR \\
\hline & Puan siralama & 4 & Avrasya-İngiliz Dil. Edb. \\
\hline & & & Belirsiz-Havacılık Yön. \\
\hline & & & Bahçeşehir-Yazılım Müh. \\
\hline & & & Bahçeşehir-Tıp \\
\hline & Kaliteli eğitim & 3 & Sabanci-Tip \\
\hline & & & Bahçeşehir-Ul. İlişkiler \\
\hline & Büyükşehir & 2 & H.Kalyoncu-Hukuk \\
\hline & & & Aydın-Genetik Mühendisliği \\
\hline & Tip eğitimi & 2 & Aydın-Tıp \\
\hline & & & Belirsiz-Tıp Fakültesi \\
\hline & Yüksek puan & 1 & Koç-Tıp \\
\hline & Tanıdık sağlama & 1 & Aydın-Psikoloji \\
\hline & Lüks şartlar & 1 & Sabanc1-Resim Öğrt. \\
\hline & İş imkânı & 1 & Bilkent-Mimarlık \\
\hline
\end{tabular}

Sınavdan yeterli puanı almalarına (4/100) bağlı olarak, bir öğrenci Avrasya üniversitesi İngiliz Dili Edebiyatı, bir öğrenci Bahçeşehir Üniversitesi Tıp Fakültesi'ni tercih edeceğini belirtmiştir. Bu öğrencilerden bazılarının görüşleri aşağıdaki gibidir: 
On İkinci Sınıf Öğrencilerinin Yükseköğretim Programı Seçimlerini Etkileyen Faktörler ve Öğretmenlik Programlarını Tercih Etme Durumları

- "Üniversite sinavinda alacă̆ım puan bu okullardan birini burslu kazanmaya yeterse kesinlikle tercih etmeyi düşünüyorum."

- "Burslu kazanırsam eğer tercih edeceğim, diğer türlü çok fazla masraflı gelir aileme. Hem okulun parasın ödeyecek hem de benim harçlı̆̆ımı verecek kadar imkanlarımız müsait değil."

On ikinci sınıf öğrencilerinin yükseköğretim programları seçimleri sırasında öğretmenlik programlarını tercih etme durumlarına ilişkin bulgular Tablo 10' da verilmiştir.

Tablo 10. On ikinci sınıföğrencilerinin yükseköğretim programları seçimleri sırasında öğretmenlik programların tercih etme durumlarına ilişkin bulgular

\begin{tabular}{|c|c|c|}
\hline Tema & Kodlar & Frekans \\
\hline \multirow{17}{*}{ Öğretmenliği tercih etmeme nedenleri } & Öğrencilerle uğraşma & 10 \\
\hline & Anlatma becerisi & 9 \\
\hline & Sabırsız olma & 6 \\
\hline & Mesleki zorluk & 5 \\
\hline & İlgi alanı & 4 \\
\hline & Kişilik özellikleri & 3 \\
\hline & Atanma zorluğu & 3 \\
\hline & Çocukları sevmeme & 2 \\
\hline & Saygınlık & 2 \\
\hline & Mesleki özellikler & 2 \\
\hline & Arkadaş davranışları & 2 \\
\hline & Kol dövmesi & 1 \\
\hline & Aile baskısı & 1 \\
\hline & Baba mesleği & 1 \\
\hline & Maaş miktarı & 1 \\
\hline & Kendini geliştirme & 1 \\
\hline & Dinleme becerisi & 1 \\
\hline \multirow{16}{*}{ Öğretmenliği tercih etme nedenleri } & Öğretmeyi sevme & 12 \\
\hline & Çocukları sevme & 7 \\
\hline & İnsan yetiştirme & 3 \\
\hline & Hedefe ulaşamama & 3 \\
\hline & Sporu sevdirme & 3 \\
\hline & İş imkânları & 3 \\
\hline & Mesleki koşullar & 2 \\
\hline & Öğrenciyle iletişim & 2 \\
\hline & Dinlemeyi sevme & 2 \\
\hline & Eğitim sistemi & 2 \\
\hline & Yardım etme & 2 \\
\hline & Vicdanlı olma & 1 \\
\hline & Çocukluk hayali & 1 \\
\hline & Hiçbir şey olamama & 1 \\
\hline & Düzenli kazanç & 1 \\
\hline & Sabirlı olma & 1 \\
\hline
\end{tabular}


Tablo 10 'da görüldüğü gibi öğretmenliği tercih etmeme nedenleri temasında on ikinci sınıf öğrencilerinin yarısından fazlası (54/100) yükseköğretim programı seçimlerinde öğretmenlik mesleğini tercih etmeyeceklerini belirtmişlerdir. Öğretmenlik mesleğinin tercih edilmeme nedenleri arasında; öğrencilerle uğraşmanın çok zor bir eylem olarak algılanması (10/100), ders anlatma becerilerinin zayıf olduğunu ve aynı konuları her sınıfta tekrar anlatmanın da çok zor olduğunu düşünmeleri (9/100), öğretmenliğin sabır ve hoşgörü isteyen bir meslek olması (6/100) yer almaktadır. Bu öğrencilerden bazılarının görüşleri aşağıdaki gibidir.

- “Öğrencilerle uğraşmayı sevmiyorum, kendi sımıfıma bakıyorum da içimden öğretmenlerimize Allah yardım etsin diyorum. Çünkü yaklaşık otuz kişinin her birinden, her kafadan ayrı bir ses çıkıyor."

- "Anlatma becerilerim çok zayıf. Ĕ̆er öğretmen olursanız ayn konular her yil benzer sinflarda anlatmak gerekiyor."

Öğretmenliği tercih etme bakımından öğrencilerin yarısına yakını (46/100) ise öğretmenlik programlarına yükseköğretim programı seçimlerinde yer vereceklerini belirtmişlerdir. Bu öğrencilerin, tercih nedenleri arasında; öğretmekten mutlu olma (12/100), çocukları sevme ve onlarla vakit geçirmekten hoşlanma (7/100) yer almaktadır. Bu öğrencilerden bazılarının görüşleri aşağıdaki gibidir:

- "Ülkemizde eğitim iyi verilmiyor, eğer iyi verilseydi her gün haberlerde şiddet, taciz olayları olmazdı. Ben öğretmen olup iyi gidişata katkı să̆lamak istiyorum."

- "Bizi anlayan öğretmen çok az, bu durumdan rahatsızım, bir öğrenciyi yerin dibine sokmak değil, karşıma alıp dertleşmek isterim."

Farklı lise türlerinde (Anadolu Lisesi, Anadolu İmam Hatip Lisesi, Mesleki ve Teknik Lise, Fen Lisesi) öğrenim görmekte olan on ikinci sınıf öğrencilerinin yükseköğretim program tercihleri arasındaki farklılıklara ilişkin bulgular Tablo 11'de verilmiştir.

Tablo 11'de görüldüğü gibi araştırmaya katılan on ikinci sınıf öğrencilerinden Anadolu liselerindeki öğrencilerin çoğu yükseköğretim programı seçimlerinde ilk tercih olarak İngilizce öğretmenliğine (9/40); Mesleki ve Teknik liselerde öğrencilerin çoğu Beden eğitimi öğretmenliğine (8/30); İmam Hatip liselerindeki öğrencilerin çoğu İlahiyat Fakültesi'ne (4/20), Fen liselerindeki öğrencilerin çoğu ise (4/10) Tip fakültesine yer vereceklerini belirtmişlerdir. 
On İkinci Sınıf Öğrencilerinin Yükseköğretim Programı Seçimlerini Etkileyen Faktörler ve Öğretmenlik Programlarını Tercih Etme Durumları

Tablo 11. Farklı lise türlerinde öğrenim görmekte olan on ikinci sinı öğrencilerinin yükseköğretim program tercihleri arasındaki farklılıklara ilişkin bulgular

\begin{tabular}{|c|c|c|}
\hline Okul Türü & Program Tercihi & Frekans \\
\hline \multirow[t]{14}{*}{ Anadolu Lisesi } & İngilizce öğretmenliği & 9 \\
\hline & Tıp Fakültesi & 5 \\
\hline & Elektrik-Elektronik Mühendisliği & 5 \\
\hline & Hukuk Fakültesi & 4 \\
\hline & Makine Mühendisliği & 3 \\
\hline & Diş Hekimliği & 3 \\
\hline & Mimarlık & 2 \\
\hline & Polis Meslek Yüksekokulu & 2 \\
\hline & Milli Savunma Üniversitesi & 2 \\
\hline & Beslenme ve Diyetetik & 1 \\
\hline & Sınıf Öğretmenliği & 1 \\
\hline & Hemşirelik & 1 \\
\hline & Yazılım Mühendisliği & 1 \\
\hline & Psikoloji & 1 \\
\hline \multirow[t]{13}{*}{ Mesleki ve Teknik Lise } & Beden Eğitimi Öğretmenliği & 8 \\
\hline & Turizm ve Otelcilik & 4 \\
\hline & Hukuk Fakültesi & 4 \\
\hline & Polis Meslek Yüksekokulu & 3 \\
\hline & Makine Mühendisliği & 2 \\
\hline & İnşaat Mühendisliği & 2 \\
\hline & Otomotiv Öğretmenliğgi & 1 \\
\hline & Adalet Meslek Yüksekokulu & 1 \\
\hline & Pazarlama & 1 \\
\hline & Sınıf Öğretmenliği & 1 \\
\hline & Müzik Öğretmenliği & 1 \\
\hline & Milli Savunma Üniversitesi & 1 \\
\hline & Tercih Belirtmeyen & 1 \\
\hline \multirow[t]{12}{*}{ İmam-Hatip Lisesi } & İlahiyat Fakültesi & 4 \\
\hline & Hukuk Fakültesi & 3 \\
\hline & Milli Savunma Üniversitesi & 2 \\
\hline & Diş Hekimliği & 1 \\
\hline & Polis Meslek Yüksekokulu & 1 \\
\hline & Psikolojik Danışma ve Rehberlik & 1 \\
\hline & İktisat & 1 \\
\hline & Hemşirelik & 1 \\
\hline & Özel Eğitim Öğretmenliği & 1 \\
\hline & Resim Öğretmenliği & 1 \\
\hline & Türkçe Öğretmenliği & 1 \\
\hline & Tercih Belirtmeyen & 3 \\
\hline \multirow[t]{5}{*}{ Fen Lisesi } & Tıp Fakültesi & 4 \\
\hline & Bilgisayar Mühendisliği & 2 \\
\hline & Makine Mühendisliği & 2 \\
\hline & Uzay ve Havacılık Mühendisliği & 1 \\
\hline & Genetik Mühendisliği & 1 \\
\hline
\end{tabular}


On ikinci sınıf öğrencilerinin yükseköğretim programlarına öğrenci seçme sistemiyle ilgili olumlu düşüncelerine ilişkin bulgular Tablo 12' de verilmiştir.

Tablo 12. On ikinci sınf öğrencilerinin yükseköğretim programlarnna öğrenci seçme sistemiyle ilgili olumlu düşüncelerine ilişkin bulgular

\begin{tabular}{llr}
\hline Tema & Kodlar & Frekans \\
\hline & Temel Yeterlik Testi zamanı & 24 \\
& Yeni sistem & 15 \\
Soru sayısı & 12 \\
Sinav aralıkları & 10 \\
Sinav süresi & 9 \\
Kolaylık öngörüsü & 8 \\
& 180 barajı & 7 \\
Olumlu düşünceler & Puanır geçerlik süresi & 3 \\
& Puan türleri & 3 \\
& Katsayı eşitliği & 2 \\
& Yaş sinırı & 2 \\
& Genel kültür sağlama & 2 \\
& Devlete vefa borcu & 1 \\
& Örnek soruların yayınlanması & 1 \\
&
\end{tabular}

Tablo 12'de görüldügü gibi olumlu düşünceler temasında araştırmaya katılan on ikinci sınıf öğrencilerinin yükseköğretim programlarına öğrenci seçme sistemiyle ilgili olumlu düşüncelerinden en fazla öne çıkanlar; Mart ayındaki sınavın Hazirana alınması (24/100), yeni bir sınav sisteminin olumlu olabileceği (15/100), soru sayılarının Sosyal ve Fen alanında azaltılması (12/100) şeklindedir. Bu öğrencilerden birinin görüşü aşağıdaki gibidir:

- "Sinavin bu yıl Haziran ayına alınması çok iyi oldu. Çalışacak epeyce bir zaman sağladı. Mart ayından sonra herkes çalışmayı bırakırdı, şimdi herkesin bir ümidi var."

On ikinci sınıf öğrencilerinin yükseköğretim programlarına öğrenci seçme sistemiyle ilgili olumsuz düşüncelerine ilişkin bulgular Tablo 13' de verilmiştir. 
Tablo 13. On ikinci sınıf öğrencilerinin yükseköğretim programlarına öğrenci seçme sistemiyle ilgili olumsuz düşüncelerine ilişkin bulgular

\begin{tabular}{llr}
\hline Tema & Kodlar & Frekans \\
\hline & Değişikliklerin sıklı̆̆ı & 20 \\
& Sistemin olumsuzluğu & 18 \\
& Soru sayıları & 12 \\
& Oturum aralıkları & 10 \\
& Yeni uygulama & 7 \\
& Matematik sorusu & 6 \\
& Temel Yeterlik Testi zamanı & 5 \\
& Konu fazlalı̆̆ı & 5 \\
Olumsuz düşünceler & Sinav süresi & 4 \\
& Çalışma süresi & 3 \\
& Sinav alternatifleri & 3 \\
& Uygulamada plansılılı & 2 \\
& Sistemin eşitsizliği & 2 \\
& Sinav yeri & 1 \\
& Yabancı dil soruları & 1 \\
& Ek puan & 1 \\
\hline
\end{tabular}

Tablo 13'te görüldüğü gibi öğrenci seçme sistemiyle ilgili olumsuz düşünceler arasında sınav sisteminin sık değiştirilmesi (20/100), sınav sisteminin yanlışlığı (18/100), sosyal ve fen soru sayılarının azaltılmış olması (12/100) yer almaktadır. Bu öğrencilerden birinin görüşü şöyledir:

- "Sürekli sinav sistemini bize sormadan değiştiriyorlar, özellikle de bu yıl iki üç kere değiştirdiler. Dönem içinde değişmesi tam da biz ders çalışmaya başlamışken moralimizi bozuyor."

On ikinci sınıf öğrencilerinin yükseköğretim programlarına öğrenci seçme sistemiyle ilgili önerilerine ilişkin bulgular Tablo 14'te verilmiştir.

Tablo 14'te görüldüğü gibi sistemle ilgili öneriler temasında araştırmaya katılan on ikinci sınıf öğrencilerinin yükseköğretim programlarına öğrenci seçme sistemiyle ilgili önerileri arasında, sınav sisteminin öğrencilerin kişisel yeterliklerini ölçecek şekilde yapılması (20/100) ve ilk sınavdaki (TYT) soru sayılarının) artırılması gerektiği (14/100) yer almaktadır. 
Tablo 14. On ikinci sınıf öğrencilerinin yükseköğretim programlarına öğrenci seçme sistemiyle ilgili önerilerine ilişkin bulgular

\begin{tabular}{llr}
\hline Tema & Kodlar & Frekans \\
\hline Sistemle ilgili öneriler & Yetenek ölçütü & 20 \\
& Soru sayıları & 14 \\
& Temel Yeterlik Testi süresi & 8 \\
Eski sisteme dönüş & 7 \\
Oturum zamanları & 6 \\
Konuların azaltılması & 6 \\
Planlı değişim & 4 \\
Meslek liseleri & 3 \\
Paragraf uzunluğu & 2 \\
Yabancı dil & 2 \\
Giriş koşulları & 2 \\
Ek puan & 2 \\
Otoriteye bırakma & 1 \\
Ortalama alınması & 1 \\
Açık uçlu soru & 1 \\
Mülakat sistemi & 1 \\
& Puan hesaplamaları & 1 \\
Sinav sistemi önerisi yok & 19 \\
\hline
\end{tabular}

\section{Sonuç, Tartışma ve Öneriler}

Çalışmanın bulgularına dayalı olarak aşağıdaki sonuçlara ulaşılmıştır:

On ikinci sınıf öğrencilerinin yükseköğretim programı seçimlerinde;

- Kişisel özelliklerinin, yetenek ve ilgilerinin etkili olabileceği,

- Ailelerinin etkisinin az olduğu,

- Arkadaşlarının etkili olma ihtimalinin düşük olduğu,

- Yükseköğretim programlarının mezunlarına sağlayacağı iş ve maddi kazancın etkili olabileceği,

- Üniversitelerin burs, yurt, sosyal aktivite, yurt dişı eğitim vb. olanaklarının etkili olabileceği,

- Yükseköğretim programlarının toplum üzerindeki imajı, statü ya da saygınlığının etkili olabileceği,

- Yükseköğretim programının ve bağlı olduğu üniversitenin akademik kadrosunun etkili olabileceği,

- Üniversitenin bulunduğu şehrin etkili olabileceği, 
- Özel üniversitelerin programlarına yer verme ihtimallerinin düşük olduğu,

- Öğretmenlik programlarına yer verme ihtimallerinin düşük olduğu sonucuna ulaşılmıştır.

- Anadolu lisesi öğrencilerinin yükseköğretim program seçimlerinde ilk sırada İngilizce Öğretmenliği'ni; Mesleki ve Teknik lise öğrencilerinin Beden Eğitimi Öğretmenliği'ni, İmam Hatip lisesi öğrencilerinin İlahiyat Fakültesi'ni, Fen lisesi öğrencilerinin ise Tıp Fakültesi'ni tercih etme düşüncesinde oldukları sonucuna ulaşılmiştır.

- Öğrencilerin yükseköğretim programlarına öğrenci seçme sistemine yönelik olumlu düşüncelerinin sınavın Haziran ayına alınmasına, olumsuz görüşlerinin sistemin sık değişmesine, önerilerinin ise sınavin yeteneklere göre yapılmasına yoğunlaştığı sonucuna ulaşılmıştır.

$\mathrm{Bu}$ araştırmadan elde edilen bulgulara göre on ikinci sınıf öğrencilerinin tamamına yakınının yükseköğretim programı seçimlerinde kişisel özelliklerinin, yetenek ve ilgilerinin etkili olacağını düşündükleri sonucuna ulaşılmıştır. Aytekin (2005) meslek seçimini etkileyen faktörlerle ilgili çalışmasında, en belirleyici faktörün ilgi ve yeteneklere uygunluk olduğunu; Berdan (2008) öğrencilerin yetenekleriyle ilgili alanlarda eğitim almalarının ne kadar önemli olduğunun anlaşıldığını ve bununla beraber mesleki rehberlik kavramının ortaya çıtığını, ancak öğretmen ve öğrencilerin yeteneklerinin hala ortak bir paydada buluşamadıklarını; Kaya (1988) meslek seçiminde ilgi ve yeteneklere uygunluğun \%68.8 oranında etkili olduğunu; Borchert (2002) ise kişiliğin kariyer seçimini etkileyen üç faktörden biri olduğu sonucuna ulaşmıştır.

Çalışmada öğrencilerin çoğunun yükseköğretim programı seçimlerinde ailelerinin etkisinin olmayacağı sonucuna ulaşılmıştır. Bu sonuca paralel olarak Bekleviş (2007), ailelerin öğrencilerinin kararına saygı duyduklarını ve onları kararlarında desteklediklerini; Vurucu (2010) meslek lisesi öğrencilerinin yalnızca \%27'sinin meslek seçimlerinde ailelerinin etkili olacağını; Dinç (2008) ise aile çevresinin öğrenciler üzerinde herhangi bir etkisinin olmadığı sonucuna ulaşmıştır. Çalışmada ayrıca, öğrencilerin çoğunun yükseköğretim programı seçimlerinde arkadaşlarından etkilenmeyeceklerini düşündükleri belirlenmiştir. Çiftçi ve 
diğerleri (2011) öğrencilerin yalnızca \%2.2'sinin yükseköğretim programı seçimlerinde arkadaşlarından etkilendiklerini; Bozgedik (2017) öğrencilerin \%64'ünün arkadaşlarının görüşlerinin etkili olmayacağı düşüncesinde oldukları sonucuna ulaşmıştır.

Araştırmaya katılan öğrencilerin çoğunun, yükseköğretim programı seçimlerinde mezunlara sağlanan iş ve maddi kazancın etkili olduğunu düşündükleri sonucuna ulaşılmıştır. Benzer biçimde Yıldız (2001), meslek seçiminde iş bulabilme imkanının yüksek olmasının, o mesleğin öğrenciler tarafından tercih edilme oranını artırdığını; Yelken (2008) ortaöğretim son sınıf öğrencilerinin bölüm tercihini etkileyen sebepler arasında mesleğin yüksek gelir sağlayıcı olmasının önemli bir yer tuttuğunu ortaya koymuştur. Çalışmada öğrencilerin çoğunun yükseköğretim programı seçimlerinde, üniversitelerin burs, yurt, sosyal aktivite, yurt dışı eğitim vb. olanaklarının etkili olacağını düşündükleri sonucuna ulaşılmıştır. Bu olanakların en başında Erasmus programı, burs imkanı, yurt yer alırken, bunları geziler, sosyal kulüpler ve sportif etkinlikler takip etmektedir. Saraçoğlu Aydın (2005) öğrencilerin, üniversitelerin başarılı öğrencilere sahip olmak için verdikleri başarı burslarının üniversiteler arasındaki rekabeti artırdığı görüşünde oldukları; Özcan (2015) öğrencilerin üniversitenin sunduğu sosyal olanakları dikkate aldıkları sonucuna ulaşmıştır.

Çalışmanın diğer bir sonucuna göre, öğrencilerin yarısından fazlasının yükseköğretim programı seçimlerinde programların toplum üzerindeki imajı, statü ya da saygınlığının etkili olacağını düşündükleri sonucuna ulaşılmıştır. Ercan (2011), Orta Doğu Teknik Üniversitesi'nin mevcut ve aday öğrencilerinin algılarına göre oluşan tercih ölçütleri üzerinde üniversitenin toplumdaki ünü, öğretiminin kalitesi, motivasyonu, iş imkanı, öğretim elemanlarının kalitesi gibi faktörlerin etkili olduğunu; Yılmaz (2012) öğrencilerin üniversite tercihini etkileyen faktörler arasında dördüncü sırada üniversitenin prestijinin ve proje başarılarının olduğunu; Soutar ve Turner (2002) ise, üniversite tercihini etkileyen faktörler arasında üniversitenin saygınlığı ve imajı olduğunu belirlemiştir. Çalışmada ayrıca öğrencilerin çoğunun, yükseköğretim programının ve bağlı olduğu üniversitenin akademik kadrosunun program seçimlerinde etkili olacağı görüşünde oldukları sonucuna ulaşılmıştır. Saydan'a (2008) göre, öğrencilerin akademik kadrolardan beklentilerinin boyutları, "ders 
içi akademik performans, öğretim elemanlarının öğrencilerle iletişimi, öğrencilerin sınıf seviyesi yükseldikçe artan empati beklentisi ve yine sınıf düzeyine göre farklılık gösteren kişisel bakım"dır. Burgaz ve Ergin Ekinci (2007) ise öğrencilerin "akademik hizmetler ve ilişkiler, akademik danışmanlık ve rehberlik" boyutlarındaki hizmetleri çok önemsedikleri sonucuna ulaşmışlardır. Çalışmaya katılan öğrencilerin çoğunun, üniversitenin bulunduğu şehrin yükseköğretim programı seçimlerinde etkili olacağı sonucuna ulaşılmıştır. Benzer biçimde Akar (2012), akademik saygınlıktan sonra üniversitenin yer aldığı konumun öğrenciler tarafından en çok dikkate alınan faktör olduğunu; Mangan ve diğerleri (2010), öğrencilerin üniversite tercihlerinde üniversitenin bulunduğu coğrafi konumun etkili olduğunu ortaya koymuşlardır.

Araştırmanın diğer bir sonucuna göre öğrencilerin çoğunun, özel üniversitelerin programlarına yükseköğretim programı seçimlerinde yer vermeyi düşünmedikleri sonucuna ulaşılmıştır. Ündey Kalpaklığlu ve Türemez (2010) öğrencilerin \%29.7'sinin vakıf üniversitelerinde eğitimin iyi düzeyde verilmediğini düşündüklerini; Çatı, İştar ve Özcan (2016) öğrencilerin çoğunun \%78.7 devlet üniversitelerini tercih edecekleri sonucunu ortaya koymuşlardır.

Öğretmenlik mesleğini tercih etme bakımından, öğrencilerin yarısından fazlasının yükseköğretim programı seçimlerinde öğretmenlik mesleğini düşünmedikleri sonucuna ulaşılmıştır. Ceviz (2018) öğretmenlerin toplumda yaptıkları işten çok, mesai saatlerini ve tatilleri konuştuklarını; Ulutaş (2017) öğretmenlik mesleğinin statüsüyle ilgili olarak \%87'nin öğretmenlik mesleğinin statüsünü düşük bulduğu sonucuna ulaşmışlardır.

Araştırmada ayrıca, Mesleki ve Teknik lisede öğrenim görmekte olan öğrencilerin yükseköğretim programı tercihlerinde kendi alanlarının dışında kalan farklı bölümleri tercih etme eğiliminde olmaları dikkat çekicidir. Baltacı ve diğerleri (2012) turizm eğitimi alan öğrencilerin turizm programını bilinçsiz olarak seçtiklerini; Yörük, Dikici ve Uysal (2002) meslek liselerinin son yıllarda kan kaybettiğini araştırma sonuçlarında belirtmişlerdir. Bu sonuçlar, öğrencilerin eğitimlerine ilişkin tercihlerde yeterince bilinçli olmadıkları algısına neden olmaktadır.

Çalışmadan elde edilen veriler ışığında uygulayıcılara ve araştırmacılara yönelik aşağıdaki öneriler ileri sürülebilir: 
- Çalışmada kişisel özelliklerin, yetenek ve ilgilerin yükseköğretim programı seçiminde etkili olabileceği belirlendiğinden, öğrencilerin yetenek alanlarını keşfetmelerini ve kendilerini gerçekleştirmelerini sağlayacak eğitim programlarının yaygınlaşması sağlanabilir.

- Çalışmada öğrencilerin öğretmenlik programlarına yer verme ihtimallerinin düşük olduğu belirlendiğinden ve Türkiye' deki öğretmen açığı dikkate alındığında, öğretmenlik mesleğinin daha iyi tanıtılması ve bilinçli olarak tercih edilebilmesi için gerekli rehberlik hizmetleri sunulmalıdır.

- Çalışmada yükseköğretim programlarının toplum üzerindeki imajı, statü ya da saygınlığının programların tercih edilmesinde etkili olabileceği belirlendiğinden, statü ve saygınlık kaybı yaşayan mesleklerin ve programların ilgili kurumlar tarafından değerlendirilerek iyileştirilmesi sağlanabilir.

- Çalışmada yükseköğretim programlarının mezunlarına sağlayacağı iş ve maddi kazancın etkili olabileceği belirlendiğinden dolayı, mesleki rehberlik hizmetlerinde öğrencilere yönelik bu konudaki bilgilendirme çalışmalarının daha nitelikli olması sağlanmalıdır.

- On ikinci sınıf öğrencilerinin görüşleri ile sınırlandırılan bu araştırma, lise kademesindeki tüm sınıfları kapsayacak şekilde yapılabilir.

- Bu araştırma yalnızca devlet okullarında yapılmıştır. Benzer bir çalışma özel okullar dahil edilerek gerçekleştirilebilir.

- Çalışmanın örneklemi sadece öğrencilerden oluştuğundan, aynı konuda öğrencilerin velilerinin, öğretmenlerinin ve okul yöneticilerinin görüşlerinin alınacağı çalışmalar yapılabilir. 


\title{
EXTENDED ABSTRACT
}

\section{Factors Affecting Twelfth Grade Students' Higher Education Choices and Their Preferences for Teacher Education Programs}

\author{
Hasan Güner Berkant - Sevim Bahadır \\ Sutcu Imam University, Cukurova Electricity High School
}

The general aim of this study is to determine the factors that affect the choice of twelfth grade students' higher education programs and their situations of preferring teacher education programs. In response to this general objective, the following questions were sought:

On the students' preferences of higher education program, what are their views towards the effect of; their personal characteristics, talents and interests; families-related factors; friends-related factors; job opportunities and financial benefits of higher education programs to be provided to graduates; opportunities of universities such as scholarships, dormitories, social activities, overseas education (Erasmus etc.); the image, status or prestige of higher education programs on society; the academic staff of the higher education program and the university it belongs to; the city where the university is located; the preference of private universities' programs; the preference of teacher education programs; type of high school they study? What are the positive and negative thoughts and suggestions of the twelfth grade students towards the student selection system in higher education programs?

\section{Method}

The sample of the study consisted of 100 students studying in the twelfth grade of the public schools in the central districts of Kahramanmaraş province in the 2017-2018 academic year. In the research, interview as a qualitative method was used to collect data. The study is based on phenomenological design and the sample was selected accordance with the 
maximum diversity sampling method. Personal information form and semi-structured interview form were used as data collection tool. The semi-structured interview form was tested on three students in pilot study. After the pilot study, the final version of the form has been evaluated in terms of its content, construct, and language validity by an education expert, two counsellors, and a branch teacher. Instead of group works, interviews were carried out individually in order to collect data from students attending to different high school types in accordance with the problem of the study. In addition, individual interviews were preferred to ask each student more question and to conduct a more in-depth examination. The data of the study were collected via voice recorder or taking notes according to the students' permessions. After the interviews were completed, the data from the voice recorder were converted into text and analyzed with the other data by using the content analysis method. Codes and themes were obtained as the results of the analysis. In order to determine the reliability of the data, a second encoder was used and consistency between coders was calculated as .94 according to Miles and Huberman's formula.

\section{Findings and Results}

According to the findings of the data analysis, it was concluded that most of the twelfth grade students' personal characteristics, interests and abilities could be effective in the preference of higher education programs. In addition, it has been concluded that the employment opportunities and financial benefits that the higher education programs can provide to their graduates, the opportunities of universities such as abroad education, scholarship, dormitory, the image of higher education programs on society, status and prestige can be effective. It was found that the academic staff of the higher education program and the university that it belongs could be effective in the preference of higher education program. Also it was found that the most desired characteristics of the staff is being knowledgeable, experienced, instructive, and friendly. It was found that the city where the university is located is too important for the students in higher education program preference and that the most desired features of the city are related with being metropolitan, cheap and a rich place in 
terms of social activity. However, most of the students thought that, their families and friends had no effect on their preference of higher education programs. It was concluded that many students would not prefer private universities for higher education because of their financial situation. It was found that many students considered teaching profession as a difficult and very demanding profession and found it difficult to teach the same subject again. It was found that students attending to vocational and technical high schools would prefer programs such as Physical Education Teacher, Tourism and Hotel Management, Faculty of Law, Police Vocational School before preferring their own fields as a higher education program. It was concluded that, about the higher education test system, twelfth grade students evaluated positively the date of the basic proficiency test the first stage of the new test system- but they evaluated negatively the changes in the exam system to be done frequently. It is concluded that the most prominent findings among the students' suggestions about the student selection system for the higher education programs are related with that an examination system should be formed according to the students' abilities.

\section{Kaynakça / References}

Akar, C. (2012). Üniversite seçimini etkileyen faktörler: İktisadi ve İdari Bilimler öğrencileri üzerine bir araştırma. Eskişehir Osmangazi Üniversitesi İ̈BF Dergisi, 7(1), 97-120.

Aytekin, A. (2005). Meslek seçimini etkileyen sosyo- ekonomik ve kültürel faktörler. Yüksek lisans tezi, Süleyman Demirel Üniversitesi Sosyal Bilimler Enstitüsü, Isparta.

Azar, A. (2011). Türkiye'deki öğretmen eğitimi üzerine bir söylem: Nitelik mi, nicelik mi? Yükseköğretim ve Bilim Dergisi, 1(1), 36-38.

Baltac1, F., Üngüren, E., Avsallı, H., ve Demirel, O. N. (2012). Turizm eğitimi alan öğrencilerin eğitim memnuniyetlerinin ve geleceğe yönelik bakış açıların belirlenmesine yönelik bir araştırma. Uluslararası Alanya İşletme Fakültesi Dergisi, 4(1), 17-25.

Baltacl, A. (2017). Nitel veri analizinde Miles-Huberman modeli. Ahi Evran Üniversitesi Sosyal Bilimler Enstitüsü Dergisi (AEÜSBED), 3(1), 1-15. 
Bekleviş, F. (2007). Öğrencilerin mesleki ilgi alanları ve ailenin meslek seçimine etkisi:Bolu ili özel dersanelerde üniversiteye hazırlı kursu gören öğrenciler üzerinde bir araştırma. Yüksek lisans tezi, Abant İzzet Baysal Üniversitesi Sosyal Bilimler Enstitüsü, Bolu.

Berdan, İ. E. (2008). Ortaöğretim kurumlarmdaki öğretmen ve öğrencilerin yeteneklerinin alan ve meslek seçimine etkileri. Yüksek lisans tezi, Beykent Üniversitesi Sosyal Bilimler Enstitüsü, İstanbul.

Borchert, M. (2002). Career choice factors of high school students. Masters Thesis, Unpublished. Stout, Menomonie, University of Wisconsin, Wisconsin.

Bozgedik, A. (2017). Eğitimde yeni bir model olan temel lise öğrencilerinin üniversite ve meslek seçimini etkileyen faktörler. Yüksek lisans tezi, Selçuk Üniversitesi Sosyal Bilimler Enstitüsü, Konya.

Burgaz, B., ve Ergin Ekinci (2007). Hacettepe üniversitesi öğrencilerinin bazı akademik hizmetlere ilişkin beklenti ve memnuniyet düzeyleri. Hacettepe Üniversitesi Ĕ̆itim Fakültesi Dergisi, 33, 120134.

Ceviz, H. (2018). Toplumdaki öğretmenlik mesleğine ilişkin algı ile öğretmenin mesleki motivasyonu arasındaki ilişki. Yüksek lisans tezi, Düzce Üniversitesi Sosyal Bilimler Enstitüsü, Düzce.

Çatı, K., İştar, E., ve Özcan, H. (2016). Üniversite tercihlerine etki eden faktörlerin incelenmesi: Türkiye genelinde bir alan araştırması. Yükseköğretim ve Bilim Dergisi, 6(2), 163-177.

Çiftçi, G. E., Bülbül, S.F., Bayar-Muluk, N., Çamur-Duyan, G., ve Yılmaz, A. (2011). Sağlık Bilimleri Fakültesi'ni tercih eden öğrencilerin üniversite ve meslek tercihlerinde etkili olan faktörler:Kırıkkale Üniversitesi örneği. The Journal of Kartal Training and Research Hospital, 22(3), 151-160.

Coşkun, K. (2006). Genel liselerde mesleki rehberlik hizmetlerinin değerlendirilmesi:Kayseri ili örneği. Yüksek lisans tezi, Erciyes Üniversitesi Sosyal Bilimler Enstitüsü, Kayseri.

Çurğatay, V. (2010). Üniversite sınavına girecek öğrencilerin meslek seçimini etkileyen sosyo-kültürel faktörler:Malatya'daki lise son sinı öğrencileri uygulaması. Yüksek lisans tezi, İnönü Üniversitesi Sosyal Bilimler Enstitüsü, Malatya. 
Demir, M. K., ve Arı, E. (2013). Öğretmen sorunları-Çanakkale ili örneği. Ondokuz Mayıs Üniversitesi Ĕ̆itim Fakültesi Dergisi, 32(1), 107-126.

Deniz, S. (2001). Bireyin meslek seçimini etkileyen kaynaklar: Yeni teknolojilerden internet. Muğla Üniversitesi Sosyal Bilimler Enstitüsü Dergisi, 6, 1-9.

Dinç, E. (2008). Meslek seçiminde etkili faktörlerin incelenmesi: Meslek yüksek okulu muhasebe programı öğrencileri üzerine bir araştırma. Kocaeli Üniversitesi Sosyal Bilimler Enstitüsü Dergisi, 16(2), 90-106.

Eraslan, L. (2004). Öğretmenlik mesleğine girişte Kamu Personeli Seçme Sınavı (KPSS) yönteminin değerlendirilmesi. Journal of Human Sciences, 1(1), 2-31.

Ercan, H. (2011). Üniversite seçiminde öğrenci alglları ve Türk üniversitelerinin konumlandırılması. Yüksek lisans tezi, İstanbul Teknik Üniversitesi Fen Bilimleri Enstitüsü, İstanbul.

Glesne, C. (2013). Nitel araştırmaya giriş. (A. Ersoy ve P. Yalçınoğlu çev.). Ankara: Anı Yayınclik.

Gushue, G. V., Clarke, C. P., Pantzer, K. M., ve Scanlan, K. R. L. (2006). Self efficacy, perceptions of barriers, vocational identity, and the career exploration behavior of Latin/a high school students. The Career Development Quartely, 54, 307-317.

Kaya, Z. (1988). Lise son sını öğrencilerinin meslek seçimindeki sosyoekonomik faktörler. Yüksek lisans tezi, İstanbul Üniversitesi Sosyal Bilimler Enstitüsü, İstanbul.

Kepçeoğlu, M. (1996). Psikolojik danışma ve rehberlik. Ankara: Özdemir Ofset.

K1lınç, A. (2007). Üniversite seçiminde öğrenci yönelimlerini etkileyen faktörler. Yüksek lisans tezi, Marmara Üniversitesi Fen Bilimleri Enstitüsü, İstanbul.

Korkut Owen, F., Kepir, D. D., Özdemir, S., Ulaş, Ö., ve Yılmaz, O. (2012). Üniversite öğrencilerinin bölüm seçme nedenleri. Mersin Üniversitesi Ĕ̆itim Fakültesi Dergisi, 8(3), 135-151.

Kuzgun, Y. (2009). Meslek gelişimi ve danışmanlı̆̆ı. Ankara: Nobel Yayın Dağıtım.

Özgüven, İ. E. (2001). Çağdaş eğitimde psikolojik danışma ve rehberlik. Ankara: Sistem Ofset. 
Mangan, J., Hughes, A., Davies, P., ve Slack, K. (2010). Fairaccess, achievement and geography: Explaining the association between social class and students' choice of university. Studies in Higher Education, 35(3), 335-350.

MEB (2018). Millî Eğitim Bakanlı̆̆1 Rehberlik Hizmetleri Yönetmeliği. http://www.resmigazete.gov.tr adresinden 17.07.2018 tarihinde erişilmiştir.

Merriam, S. B. (2015). Nitel araştırma desen ve uygulama için bir rehber. (S. Turan çev.). Ankara: Nobel Akademik Yayıncılık.

Miles, M, B., ve Huberman, A. M. (1994). Qualitative data analysis: An expanded Sourcebook. (2 ${ }^{\text {nd }}$ ed.). Thousand Oaks, CA: Sage.

Nagel, G. K. (1999). Öğrenmenin taosu. (B. Kuryel çev.). İstanbul: Beyaz Yayınları.

Özbek, R. (2007). Öğretmen adaylarının öğretmenlik mesleğini tercih etmelerinde kişisel, ekonomik ve sosyal faktörlerin etkililik derecesine ilişkin algıları. Fırat Üniversitesi Sosyal Bilimler Dergisi, 17(1), 145-159.

Özbek, R., Kahyaoğlu, M., ve Özgen, N. (2007). Öğretmen adaylarının öğretmenlik mesleğine yönelik görüşlerinin değerlendirilmesi, Sosyal Bilimler Dergisi, 9(2), 222-232.

Özcan, H. (2015). Öğrencilerin üniversite tercihine etki eden faktörler üzerine bir araştırma. Yüksek lisans tezi, Düzce Üniversitesi Sosyal Bilimler Enstitüsü, Düzce.

Özgüven, İ. E. (2001). Çağdaş eğitimde psikolojik danışma ve rehberlik. Ankara: Sistem Ofset.

Özsoy, G., Özsoy, S., Özkara, Y., ve Memiş, A. D. (2010). Öğretmen adaylarının öğretmenlik mesleğini tercih etmelerinde etkili olan faktörler. Elementary Education Online, 9(3), 910-921.

Paa, H. K., ve McWhirter, E. H. (2009). High school students current career expectations. The Career Devolopment Qartely, 49, 29-44.

Saraçoğlu-Aydın, A. (2005). Öğrencilerin üniversite seçiminde halkla ilişkiler ve tanttım faaliyetlerinin etkisi: Gazi Üniversitesi örneği. Yüksek lisans tezi, Gazi Üniversitesi Eğitim Bilimleri Enstitüsü, Ankara.

Saydan, R. (2008). Üniversite öğrencilerinin öğretim elemanlarından kalite beklentileri: Yüzüncü Yll üniversitesi İ̈BF örneği. Gazi Üniversitesi İktisadi ve İdari Bilimler Fakültesi Dergisi, 1(10), 63-79. 
Soutar, G., ve Turner, J. (2002). Students' preferences for university: A conjoint analysis. The International Journal of Educational Management, 16(1), 40-45.

Şirin, A., Öztürk, R., Bezci, G., Çakar, G., ve Çoban, A. (2004). Hemşirelik öğrencilerinin meslek seçimi ve mesleği uygulamaya yönelik görüşler. III. Ulusal Hemşirelik Öğrencileri Kongresi, 29-30 Nisan, Edirne, (69-75).

Ulutaş, P. (2017). Öğretmenlerin bakış açısından öğretmenlik mesleğinin statüsü. Yüksek lisans tezi, Mersin Üniversitesi Eğitim Bilimleri Enstitüsü, Mersin.

Ündey Kalpaklioğlu, N., ve Türemez, Y. (2010). Üniversite adaylarının vakıf üniversitesi tercihlerinde halkla ilişkiler çalışmalarının etkisi. ABMYO Dergisi, 17, 47-58.

Vurucu, F. (2010). Meslek lisesi öğrencilerinin meslek seçimi yeterliliği ve meslek seçimini etkileyen faktörler. Yüksek lisans tezi, Yeditepe Üniversitesi Sosyal Bilimler Enstitüsü, İstanbul.

Yavuzer, H. (2001). Doğum öncesinden ergenlik sonuna:Çocuk psikolojisi. İstanbul: Remzi Kitabevi.

Yelken, K. (2008). Ortaöğretim son sinıföğrencilerinin üniversite tercihlerini ve meslek seçimini etkileyen faktörler:Sakarya il merkezi örneği. Yüksek lisans tezi, Sakarya Üniversitesi Sosyal Bilimler Enstitüsü, Sakarya.

Yeşilyaprak, B. (2000). Eğitimde rehberlik hizmetleri. Ankara: Nobel Yayın Dağıtım.

Yıldırım, A., ve Şimşek, H. (2015). Sosyal bilimlerde nitel araştırma yöntemleri. Ankara:Seçkin Yayıncılık,

Yıldız, S. (2001). Kişilik ve meslek seçimi arasındaki ilişki ve bir uygulama. Yüksek lisans tezi, Uludağ Üniversitesi Sosyal Bilimler Enstitüsü, Bursa.

Yılmaz, N., ve Doğan, N. (2015). İlköğretim matematik öğretmen adaylarının meslek tercihlerini etkileyen faktörler: Hacettepe üniversitesi örneği. Abant İzzet Baysal Üniversitesi Ĕ̆itim Fakültesi Dergisi, 15(1), 405-421. 
Y1lmaz, Ö. (2012). Öğrencilerin üniversite tercihlerini etkileyen kriterlerin belirlenmesinde analitik hiyerarşi proses uygulaması ve Süleyman Demirel üniversitesi örneği. Yüksek lisans tezi, Süleyman Demirel Üniversitesi Sosyal Bilimler Enstitüsü, Isparta.

Yörük, S., Dikici, A., ve Uysal, A. (2002). Bilgi toplumu ve Türkiye'de mesleki eğitim, Fırat Üniversitesi Sosyal Bilimler Dergisi, 12(2), 299-312.

Yüksel Şahin, F. (2008). Ortaöğretimdeki öğrenci görüşlerine göre Psikolojik danışma ve rehberlik (PDR) hizmetlerinin değerlendirilmesi. Uluslararası Insan Bilimleri Dergisi, 5(2), 1303-5134.

\section{Kaynakça Bilgisi / Citation Information}

Berkant, H. G. ve Bahadır, S. (2019). On ikinci sınıf öğrencilerinin yükseköğretim programı seçimlerini etkileyen faktörler ve öğretmenlik programlarını tercih etme durumları. OPUS-Uluslararası Toplum Araştırmaları Dergisi, 11(18), 1897-1940. DOI: 10.26466/ opus.567578 